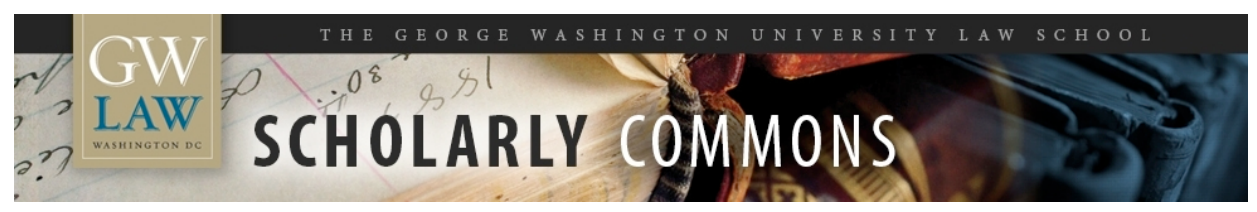

\title{
Assessing the Legality of Counterterrorism Measures Without Characterizing Them as Law Enforcement or Military Action
}

\author{
Gregory E. Maggs \\ George Washington University Law School, gmaggs@law.gwu.edu
}

Follow this and additional works at: https://scholarship.law.gwu.edu/faculty_publications

Part of the Law Commons

\section{Recommended Citation}

Gregory E. Maggs, Assessing the Legality of Counterterrorism Measures Without Characterizing Them as Law Enforcement or Military Action, 80 Temp. L. Rev. 661 (2007).

This Article is brought to you for free and open access by the Faculty Scholarship at Scholarly Commons. It has been accepted for inclusion in GW Law Faculty Publications \& Other Works by an authorized administrator of Scholarly Commons. For more information, please contact spagel@law.gwu.edu. 


\title{
ASSESSING THE LEGALITY OF COUNTERTERRORISM MEASURES \\ WITHOUT CHARACTERIZING THEM AS \\ LAW ENFORCEMENT OR MILITARY ACTION
}

\author{
by Gregory E. Maggs*
}

\section{INTRODUCTION}

II. HOW DEBATES OVER THE LEGALITY OF COUNTERTERRORISM MEASURES NOW TURN ON WHETHER THE MEASURES ARE CHARACTERIZED AS LAW ENFORCEMENT OR MILITARY ACTION
A. Authority to Use Force in Foreign Countries
B. Authority to Use Force Domestically
C. Targeted Killing
D. Detention
E. Trials
F. Search and Seizure
G. Duty to Provide Security
H. Compensation for Harm
I. Other Issues

III. PROBLEMS WITH DETERMINING THE LEGALITY OF COUNTERTERRORISM MEASURES BY ATTEMPTING TO CHARACTERIZE THEM AS LAW ENFORCEMENT OR MILITARY ACTION
A. No Standard for Making the Characterization Exists
B. Counterterrorism Measures Fit Neither Characterization Perfectly
C. Either Characterization Sometimes Produces Unfavorable Results
D. The Current System Gives the Government Considerable Discretion to Determine the Legality of its Own Actions
IV. THE ADVANTAGES OF SEEING COUNTERTERRORISM MEASURES AS A SEPARATE FORM OF GOVERNMENTAL ACTION
A. Benefits of Judging Counterterrorism Measures as Counterterrorism Measures
B. How to Change the Current Approach
C. For the Skeptical: Consider the Alternatives
D. Emerging Examples of the Recommended Approach

V. CONCLUSION

\footnotetext{
* Professor of Law, George Washington University Law School. I would like to thank Dean Fred Lawrence and Professors Orin Kerr, Jonathan Siegel, and Peter Smith for their comments and suggestions. In my capacity as a reserve officer in the U.S. Army Judge Advocate General's Corps, I have worked on terrorism related issues, including those concerning military commissions. The views expressed here are my own and do not necessarily reflect those of the U.S. Army or the Department of Defense. The George Washington University Law School provided generous financial support.
} 


\section{INTRODUCTION}

Nations around the world are responding to terrorism with a combination of law enforcement measures and military action. ${ }^{1}$ In the United States, for example, the federal government has prosecuted terrorists responsible for the 1993 World Trade Center bombing, ${ }^{2}$ the 1998 assaults on U.S. embassies in Kenya and Tanzania, ${ }^{3}$ and the attacks of September 11, 2001. At the same time, the government also has been using its armed forces against al-Qaida terrorists in Afghanistan, Iraq, Sudan, Yemen, and other places. ${ }^{5}$ Other countries also are fighting terrorism with both criminal proceedings and military force, including Egypt, ${ }^{6}$ Israel, ${ }^{7}$ Russia, ${ }^{8}$ Turkey, ${ }^{9}$ and the United Kingdom. ${ }^{10}$

\footnotetext{
${ }^{1}$ For a general treatment of law enforcement, military, and other governmental responses to terrorism, see GREGORY E. MAGGS, TERRORISM AND THE LAW: CASES AND MATERIALS (2005).

${ }^{2}$ See United States v. Salameh, 152 F.3d 88 (2d Cir. 1998), cert. denied 525 U.S. 1112 (1999) (prosecution of terrorists who detonated a van full of explosives under one of the towers of the World Trade Center in New York City, killing six, injuring 1400 others, and caused over $\$ 500$ million of property damages).

${ }^{3}$ See United States v. Bin Laden, Transcript of Sentencing Hearing, No. S(7), 98 Cr. 1023 (S.D.N.Y. Oct. 18, 2001), available at $<$ available at $<$ http://cryptome.org/usa-v-ubl-78.htm $>$ (sentencing of terrorists who participated in the bombing of the American Embassies in Nairobi, Kenya, and Dar es Salaam, Tanzania, killing 224 people and wounding thousands of others).

${ }^{4}$ The United States has convicted Zacarias Moussaoui of conspiring with the hijackers involved in the 9/11 attacks. See See Neil A. Lewis, Moussaoui Given Life Term by Jury over Link to 9/11, N.Y. TIMES, May 4, 2006.

${ }^{5}$ Complete official news on the United States' military campaign against terrorism is available at $<$ http://www.defendamerica.mil >. Discussion of several of military responses appears in part II below.

${ }^{6}$ See Susan Sachs, A Nation Challenged: Bin Laden's Allies; An Investigation in Egypt Illustrates Al Qaeda's Web, N.Y. TIMES, Nov. 21, 2001, at A1 (describing major anti-terrorism prosecutions in Egypt); Associated Press, Egypt Sentences 6 To Death for Attacks, N.Y. TIMES, Jan. 14, 1996, at 12 (describing military process used against suspected terrorists).

${ }^{7}$ See Uri Dan, Israel Blows Away 2 Top Terrorists, N.Y. Post, Nov. 2, 2005, at 30 (describing targeted killing of suspected terrorists); Charles A. Radin, Palestinian Leader Convicted in Israel Five Life Terms Sought in Killings, BOSTON GLOBE, May 21, 2004, at A8 (describing prosecution of terrorists in Israel).

${ }^{8}$ See Nadezhda Gaisenok \& Alexander Shashkov, Russia Court to Examine Appeal of 3 Chechens Convicted for Terror, TASS, Nov. 9, 2005 (discussing criminal prosecution of terrorists in Russia); David Holley, Separatists Tied to '99 Bombings, L.A. Times, May 1, 2003, at 5 (discussion Russian military responses to terrorist bombings of apartment buildings in Moscow).

${ }^{9}$ See Andrew Finkel, A Foregone Conviction; the Trial of Kurdish Leader Abdullah Ocalan Is Set to Begin in Turkey amid Questions of Fairness, Time, Jun. 7, 1999, at 39; Sam Cohen, Turkey's Military Rulers Post a Sharp Decline in Terrorism, CHRISTIAN SCIENCE MONITOR, Nov. 25, 1980, at 6 (addressing Turkey's military responses to terrorism).
} 
When governments respond to terrorism, a debate often arises about the legality of the steps taken. As this article will show with numerous examples, the debate has familiar contours. Opponents of counterterrorism measures typically argue that they violate legal guarantees designed to protect criminal suspects. They assert, for instance, that domestic and international laws do not permit the government simply to shoot suspected terrorists, or to detain them indefinitely, or to try them outside of ordinary courts. But governments and their supporters have a standard reply to this objection. They assert that they are not merely addressing crime, but instead are fighting a war against terrorism, and that the law applicable to armed conflict allows them to employ the measures that they have used. In the United States, the familiar refrain is: "We took these kinds of actions in World War II when we were fighting the Nazis and the Japanese, and therefore we can take them in the war that we are fighting against al-Qaida."11

So at present debates about the legality of governmental responses to terrorism often boil down to disagreements about which law governs. Is it the law that regulates law enforcement actions? Or is it the law of armed conflict? The choice matters. Those who believe that the rules that apply to law enforcement actions must govern military responses to terrorism consider many of the responses that governments actually have taken to be illegal. And those who believe that the law of armed conflict applies tend to think that they fall wholly within accepted standards of war fighting.

Take the issue of targeted killing. A country engages in targeted killing when it locates and summarily kills a suspected terrorist. The United States has engaged in this practice in its

\footnotetext{
${ }^{10}$ See David Leppard \& Richard Woods, Britain's Secret War on Terror, SundAY TIMES, Mar. 13, 2005 , at 16 (describing the use of trials to combat terrorism); Brian Lavery, Britain to Halve its Forces in Ulster, INT'L HERALD TRIB., Aug. 3, 2005, at 3 (describing British military responses to terrorism in Northern Ireland).
} 
struggle against terrorism. For example, in the summer of 2006, the Air Force killed Abu Musab al-Zarqawi, the leader of in al-Qaeda in Iraq, by locating his safe house and then dropping bombs on his house. ${ }^{12}$ A few years earlier, the CIA fired missiles at suspected members of al-Qaida in Yemen, without trying to bring them into custody. ${ }^{13}$ Israel also has done targeted killing, attacking Palestinians in the West Bank, Syria, and other places. ${ }^{14}$ And Russia reportedly once sent a poisonous letter to kill a Chechen leader. ${ }^{15}$

Is the targeted killing of suspected terrorists lawful? As explained more fully below, ${ }^{16}$ everyone agrees that ordinary law enforcement rules in the United States (and in most other places) do not generally permit the police simply to kill criminal suspects. Instead, they must attempt to arrest them. The police can use deadly force only to prevent a suspect from escaping, and then only if the suspect poses a threat of serious physical harm to others and, if feasible, the police previously have given the suspect a warning. ${ }^{17}$ In contrast, long established principles of the law of war say that military forces generally may target and kill enemy forces in the course of a lawful armed conflict, wherever they find them, and without giving them a chance to surrender, unless the enemy forces already have lain down their weapons and given themselves up. ${ }^{18}$

\footnotetext{
${ }^{11}$ See, e.g., Thomas Sowell, Fanatics in Court, Sun-SENTINEL, Jul. 26, 2002, at 31A ("We never threw open our courtroom doors to captured Nazi prisoners of war in World War II, much less gave them access to our press.").

${ }^{12}$ Farnaz Fassihi, et al., Fateful Strike: Zarqawi's Death, Completion of Cabinet Raise Hopes in Iraq, WALl ST. J., Jun. 9, 2006, at A-1.

${ }^{13}$ See Reuters, Rights Group Questions Attack; Amnesty Says U.S. Missile Strike in Yemen May be Illegal, WASH. Post, Nov. 9, 2002 at A21 (describing an incident in which the CIA killed persons suspected of participating in the bombing of the U.S.S. Cole). For further discussion, see part II.C. infra.

${ }^{14}$ See Joel Greenberg, Palestinian Militant Slain in Damascus; Israel Blamed; Revenge Vowed, ChiCAGo TrIBUNE, Sept. 27, 2004, at 3 (describing Israel's practice of targeted killing).

${ }^{15}$ See Peter Baker, Russia Moving to Eliminate Chechen Rebel Leaders, WASH. Post, Apr. 20, 2004, at A13 (reporting that Russia reported killa guerrilla called "Khattab" in 2002 with a poisoned letter).

${ }^{16}$ See infra part II.B. (describing legal rules that may apply to targeted killing).

${ }^{17}$ See Tennessee v. Garner, 471 U.S. 1, 11 (1985).

${ }^{18}$ See U.S. Army Field Manual 27-10, The Law of Land Warfare, ch. 2, sec. II, $\uparrow 29$ (1956) (citing Annex to Hague Convention No. IV, Oct. 18, 1907, embodying the Regulations Respecting the Laws and Customs of War on Land, art. 23(c)).
} 
But what do these two sets of rules say about the targeted killing of suspected terrorists? At present, the answer appears to depend on which of the two sets of rules apply. Opponents of targeted killing might view suspected terrorists as criminal suspects, concluding that the government cannot simply target and kill them. Meanwhile, proponents of targeted killing by military forces might consider the suspected terrorists to have the status of enemy combatants in an armed conflict. If the two sides disagree on the proper characterization of the suspected terrorists and of the governmental action taken against them, they will reach conflicting views about which set of legal rules should apply. In turn, they will arrive at different conclusions about the legality of any targeted killing.

In this article, I make three claims concerning this issue. In part II, I claim that characterizing counterterrorism measures as either law enforcement efforts or military actions for the purpose of determining their legality is now and long has been a central feature of counterterrorism law. Disputes over characterization have arisen in no fewer than eight different subject areas, ranging from targeted killing to the responsibility of the government to provide compensation to persons inadvertently injured by the governmental action. Disagreements about characterization further have arisen not only in the United States but also in many foreign countries. And these disputes are not new; they have occurred for many decades.

In part III, I claim that determining the legality of governmental responses to terrorism by attempting to characterize counterterrorism measures as either law enforcement or military action is not a good system. Terrorists, and counterterrorism efforts, generally defy simple characterization into one category or another because terrorists resemble enemy combatants in some ways and criminal suspects in others. In addition, the different subject areas in which the 
issue of characterization arises vary from each other in so many respects that a characterization that makes sense in one area does not necessarily make sense in another. In fact, as the article will show, the United States has found it difficult to take a consistent view on characterization, despite the centrality of the question.

In part IV, I claim that the law would be improved by moving to a system that judges counterterrorism measures as counterterrorism measures, without trying to characterize them as either law enforcement actions or military actions. In other words, the United States and other nations ought to develop new standards to regulate governmental responses to terrorism, rather than debating whether the laws of war or the rules of law enforcement should apply. Already imperfect examples of this alternative approach are emerging. They include both the Israeli Supreme Court's 2006 decision on targeted killing and, to some extent, the thinking behind the Military Commission Act of 2006. ${ }^{19}$

\section{HOW DEBATES OVER THE LEGALITY OF COUNTERTERRORISM MEASURES NOW TURN ON WHETHER THE MEASURES ARE CHARACTERIZED AS LAW ENFORCEMENT OR MILITARY ACTION}

The following demonstrates how, for many years, courts and others have judged the legality of counterterrorism measures by characterizing them as law enforcement or military action. ${ }^{20}$ This observation holds true for a wide variety of different kinds of responses to terrorism, in domestic, foreign, and international law.

\section{A. Authority to Use Force in Foreign Countries}

\footnotetext{
${ }^{19}$ See infra part IV.D.
} 
May a nation lawfully respond to a terrorist incident by using military force in a foreign country? This question often has great importance. Terrorist organizations sometimes have foreign bases of operation. In addition, after committing their assaults, terrorists often flee across borders. For these reasons, the United States and other nations may wish to make counterattacks abroad. The U.N. Charter generally forbids nations to use military force in foreign countries. Article 2(4) says: "All Members shall refrain in their international relations from the threat or use of force against the territorial integrity or political independence of any state, or in any other manner inconsistent with the Purposes of the United Nations." ${ }^{21}$ But the U.N. Charter has an exception in article 51 recognizing that nations have a right to use force when responding in self-defense to an "armed attack.",22

So the precise legal issue is this: If a nation responds to a terrorist incident by using military force in a foreign country, does that violate the U.N. Charter? If the terrorist incident was an "armed attack" within the meaning of article 51, then the response may be lawful. But if the terrorist incident was not an "armed attack," but instead merely a crime, then the response would violate the prohibition in article 2(4).

In past instances, national governments and international organizations have drawn conflicting conclusions on the very basic question of whether terrorists are just criminals or whether they are forces capable of mounting an "armed attacked." As a result, observers have

\footnotetext{
${ }^{20}$ The discussion makes no claims about which side of the debate has the better argument as matter of policy or which side should win in the courts.

${ }^{21}$ Charter of the United Nations, 1945, art. 2(4), 1 UNTS 16 [hereinafter "U.N. Charter"].

${ }^{22} \mathrm{Id}$. art. 51 ("Nothing in the present Charter shall impair the inherent right of individual or collective self-defence if an armed attack occurs against a Member of the United Nations, until the Security Council has taken measures necessary to maintain international peace and security. Measures taken by Members in the exercise of this right of self-defence shall be immediately reported to the Security Council ....”).
} 
different views about the lawfulness of extra-territorial military responses to terrorism. Here are three prominent examples.

(1) In 2004, at the request of the United Nations General Assembly, the International Court of Justice issued an advisory opinion on the legality of a lengthy fence or separation barrier constructed by Israel. ${ }^{23}$ Israel built the barrier to block terrorists from entering Israel. ${ }^{24}$ The barrier partially follows Israel's internationally recognized borders, but in many places it also runs through the occupied territory of the West Bank. ${ }^{25}$

The International Court of Justice considered, among other issues, whether article 51 could excuse Israel's use of force (i.e., the building of the fence) outside of its borders as a measure taken in self-defense. ${ }^{26}$ The court concluded that it could not, giving two alternative reasons. First, the court said that "Article 51 of the Charter ... recognizes the existence of an inherent right of self-defence in the case of armed attack by one State against another State" and that "Israel does not claim that the attacks against it are imputable to a foreign State." 27 Second, the court said that the threat originated from territory that Israel controls, and that Article 51 therefore does not apply. ${ }^{28}$

\footnotetext{
${ }^{23}$ See Legal Consequences of the Construction of a Wall in the Occupied Palestinian Territory, 2003 I.C.J. No. 131 (advisory opinion of Jul. 9, 2004).

${ }^{24}$ See id. $\uparrow 116$.

${ }^{25}$ See id. $\uparrow 122$.

${ }^{26}$ See id. $\uparrow$ 138. Israel did not press a substantive argument before the court. It contended that General Assembly had acted in an ultra vires manner in seeking an advisory opinion because the Security Council was actively addressing the Israeli-Palestinian conflict. See id. 124 . In addition, because the General Assembly was seeking an advisory opinion, and had not named Israel as party to the lawsuit, Israel had no duty to make a substance argument. See id. (declaration of Judge Burgenthal), at 910 . But the Court noted that Israel previously had told the United Nations General Assembly that it was constructing the fence in self-defense. Israel cited Security Council Resolution No. 1368 to support its argument. See id. 138.

${ }^{27} I d$. 139.

${ }^{28}$ See id.
} 
In other words, the court concluded that Israel cannot use force but must instead use ordinary law enforcement measures to deal with the terrorist threat. ${ }^{29}$ Praising the decision, Professor Mary Ellen O’Connell has written: “the situation Israel faced at the time of the Advisory Opinion was more akin to terrorist attacks perpetrated by the state's own nationals within the state's own territory because of the measure of control Israel exercises over the occupied territories. Terrorist attacks by nationals within their own state have invariably been treated as criminal. ..."30

But not everyone agrees with this position. Judge Burgenthal of the International Court of Justice filed a separate declaration in the case. Although he principally asserted that the court should not have exercised jurisdiction, ${ }^{31}$ he also specifically disagreed with the court's reasons for rejecting Israel's self-defense argument. He asserted that the U.N. charter does not permit self-defense only against armed attacks from other nations and that it was "irrelevant" whether Israel controlled the occupied territories. ${ }^{32}$ In his view, in assessing Israel's position under article 51, the court should have judged Israel's actions by their "necessity and proportionality." ${ }^{, 33}$ In other words, Judge Burgenthal did not think that nations were necessarily restricted to using only law enforcements measures against terrorist acts.

(2) On September 11, 2001, members of al-Qaida infamously hijacked and crashed four aircraft in the United States. The United States responded by using military force against alQaida in Afghanistan. In pursuing this action, the United States took the position that it was

\footnotetext{
${ }^{29}$ See Mary Ellen O'Connell, Enhancing the Status of Non-state Actors through a Global War on Terror?, 43 COLUM. J. TRANSNAT'L L. 435, 451 (2005).

${ }^{30} I d$.

${ }^{31}$ See 2003 I.C.J. No. 131 (declaration of Judge Burgenthal) at 1.

${ }^{32}$ See id. $\uparrow 6$.

${ }^{33} \mathrm{Id}$.
} 
fighting a war and could do what the laws applicable to armed conflict allow. The United States informed the United Nations Security Council, as article 51 requires, that it was acting in selfdefense in response to an "armed attack." ${ }^{34}$ The United States also persuaded NATO to agree to this characterization of the terrorist attacks. ${ }^{35}$

But not all observers share the United States and NATO's view. The Security Council itself never specifically called the terrorist incidents an "armed attack." Instead, it issued a diplomatically worded statement both condemning the assaults and "[r]ecognizing the inherent right of individual or collective self-defence in accordance with the Charter." ${ }^{36}$ The statement did not specifically say that the Charter authorized the use of force by the United States. ${ }^{37}$

Professor Sean Murphy has offered an explanation for why some might consider the events of September 11th not to rise to the level of an armed attack. ${ }^{38}$ Murphy notes that the terrorists did not operate as military or paramilitary units and that they were armed only with box cutters— "not weapons one would normally associate with military or paramilitary units.",39 Although he does not endorse the position, he raises the question whether "this was not an 'armed attack' but, rather, a use of force or intervention below the threshold of armed attack,

\footnotetext{
${ }^{34}$ See U.N. Charter, supra note 21, art. 51 ("Measures taken by Members in the exercise of this right of self-defence shall be immediately reported to the Security Council ....").

${ }^{35}$ North Atlantic Treaty Organization, Statement by NATO Secretary General Lord Robertson, available at $<$ www.nato.int/docu/speech/2001/s011002a.htm> ("[I]t has now been determined that the attack against the United States on 11 September was directed from abroad and shall therefore be regarded as an action covered by Article 5 of the Washington Treaty, which states that an armed attack on one or more of the Allies in Europe or North America shall be considered an attack against them all.").

${ }^{36}$ S.C. Res. 1368, U.N. SCOR, 4370th mtg., U.N. Doc. S/Res/1368 (2001).

${ }^{37}$ See id.

${ }^{38}$ See Sean D. Murphy, Terrorism and the Concept of "Armed Attack" in Article 51 of the U.N. Charter, 43 HARV. INT'L L.J. 41 (2002).

${ }^{39} I d$. at 45 .
} 
which is perhaps better characterized as a conventional (albeit heinous) criminal act."40 If that is the correct characterization, then only law enforcement measures would be permissible.

(3) In 1998, following attacks by al-Qaida on U.S. embassies in Kenya and Tanzania, the United States responded by firing missiles at suspected al-Qaida targets in Sudan and Afghanistan. ${ }^{41}$ The United States informed the Security Council, again as article 51 requires, that it was acting in self-defense to an armed attack. ${ }^{42}$

But others disagree with this characterization of the bombings. Sudan has protested the action. $^{43}$ And some scholars have judged the United States in law enforcement terms; Professor Jules Lobel says: "It is self-serving hypocrisy for the United States to attack alleged terrorist facilities, violate other nations' sovereignty, and kill innocent civilians, using evidence that would not suffice to sustain a criminal prosecution.",44

Other extra-territorial uses of military force to respond to terrorist attacks have led to similar debates about the applicability of article 51. The United Nations General Assembly condemned the United States' 1986 strike on Libya in response to a nightclub bombing in Berlin. ${ }^{45}$ And the Security Council (with the United States abstaining) condemned Israel's 1985

\footnotetext{
${ }^{40} \mathrm{Id}$. at 46.

${ }^{41}$ See El-Shifa Pharmaceutical Industries Co. v. United States, 378 F.3d 1346 (Fed. Cir. 2004), cert. denied 125 S. Ct. 2963 (2005) (discussing these attacks).

${ }^{42}$ The second sentence of article 51 requires a nation exercising self-defense to notify the security council. See U.N. Charter art. 51 ("Measures taken by Members in the exercise of this right of self-defence shall be immediately reported to the Security Council ....”). The United States fulfilled this requirement by sending a letter describing the reasons for the attacks in Sudan and Afghanistan. See Letter from Bill Richardson, U.S. Permanent Representative to the United Nations, to Danilo Turk, President, U.N. Security Council, U.N. Doc S/1998/780 (Aug 20, 1998).

${ }^{43}$ See Craig Turner, Sudan Gets Little Support for a U.N. Probe of U.S. Attack, L.A. TimeS, Aug. 25, 1998 , at A6.

${ }^{44}$ See Jules Lobel, The Use of Force to Respond to Terrorist Attacks: The Bombing of Sudan and Afghanistan, 24 YALE J. INT'L L. 537, 551 (1999).

${ }^{45}$ The United States viewed the terrorist incident was an armed attack, and that it therefore concluded that it could use military force in self-defense under article 51. But the United Nations General Assembly passed a resolution that "[c]ondemns the military attack perpetrated against the Socialist People's Libyan Arab Jamahiriya on 15 April
} 
bombing of the Palestinian Liberation Organization headquarters near Tunis in response to an attack on a Tunisian synagogue. ${ }^{46}$ In each of these many incidents, observers disagreed about the legality of a government response to terrorism because they disagreed about whether to characterize it as a response to crime or an act taken in an armed conflict.

\section{B. Authority to Use Force Domestically}

Is it lawful for a nation to use military force domestically in response to terrorism? The laws of each country will provide a different answer. But again the answer generally turns on whether the perpetrators are characterized as criminal suspects or as enemy combatants, and thus whether the government in responding is fighting crime or fighting a war. Usually there are two bodies of law, one for law enforcement and one for armed conflicts, and governmental responses to terrorism must be pigeon-holed into one or the other whenever a legal dispute arises. In the United States, as in other countries, federal law limits the domestic use of military forces. The Posse Comitatus Act, in particular, makes it a crime for any government official to use the Armed Forces for law enforcement purposes. ${ }^{47}$ The historic purpose of the Act was to end the use of federal troops in the former areas of the Confederacy after the Civil War."48 But the law has modern justifications as well. The Act preserves federalism by making state and local

\footnotetext{
1986, which constitutes a violation of the Charter of the United Nations and of international law ...." G.A. Res. 38, U.N. GAOR, 41st Sess., 78th plenary mtg., U.N. Doc. A/RES/41/38 (Nov. 20, 1986).

${ }^{46}$ Israel asserted that it was acting in self-defense in response to an armed attack as permitted under article 51. But the Security Council (with the United States abstaining) passed a resolution saying that it "[c]ondemns vigorously the act of armed aggression perpetrated by Israel against Tunisian territory in flagrant violation of the Charter of the United Nations International Law and norms of conduct . ..." S.C. Res. 573, U.N. SCOR, 2615th meeting, U.N. Doc. S/Res/573 (1985).

47 The Posse Comitatus Act says: "Whoever, except in cases and under circumstances expressly authorized by the Constitution or Act of Congress, willfully uses any part of the Army or the Air Force as a posse comitatus or otherwise to execute the laws shall be fined under this title or imprisoned not more than two years, or both.” 18
} 
governments responsible for most law enforcement. It also guards against the possibility that soldiers who lack training for law enforcement activities do not violate the civil liberties of citizens.

But is responding to terrorism a law enforcement measure or a military action? Two recent incidents have raised this question. One involves an American citizen named Jose Padilla. According to stipulated (but not proved) facts:

Padilla ... associated with forces hostile to the United States in Afghanistan and took up arms against United States forces in that country in our war against al Qaeda. Upon his escape to Pakistan from the battlefield in Afghanistan, Padilla was recruited, trained, funded, and equipped by al Qaeda leaders to continue prosecution of the war in the United States by blowing up apartment buildings in this country. Padilla flew to the United States on May 8, 2002, to begin carrying out his assignment .... ${ }^{49}$

Federal agents took Padilla into custody at Chicago's O'Hare airport. ${ }^{50}$ They initially held him as a material witness to a grand jury proceeding. ${ }^{51}$ But the President later designated him an "enemy combatant." ${ }^{52}$ Afterward, with the blessing of the federal courts, the United States military held Padilla in a naval brig for several years. ${ }^{53}$ Still later, the United States indicted Padilla and took him into criminal custody. ${ }^{54}$

In extensive litigation, the federal courts considered a number of issues regarding Padilla's confinement. ${ }^{55}$ Padilla at one point challenged his custody by the military as a violation

U.S.C. $\S 1385$. A "posse comitatus" is a "group of citizens who are called together to assist the sheriff in keeping the peace." BLACK'S LAW DiCTIONARY 1200 (Bryan A. Garner, ed., 8th ed. 1999).

${ }^{48}$ Chandler v. United States, 171 F.2d 921, 936 (1st Cir. 1948), cert. denied 336 U.S. 918 (1949).

${ }^{49}$ Padilla v. Hanft, 423 F.3d 386, 386 (4th Cir. 2005), cert. denied, 26 S. Ct. 1649 (2006).

${ }^{50}$ See id.

${ }^{51}$ See id. at 390.

${ }^{52}$ See id. at 388.

${ }^{53}$ See id. at 390.

${ }^{54}$ See Padilla v. C.T. Hanft, 126 S. Ct. 1649 (2006) (Kennedy, J., concurring denial of certiorari) (describing Padilla's classification and reclassification).

${ }^{55}$ See id. at 397 (upholding Padilla's confinement). 
of the Posse Comitatus Act. ${ }^{56}$ He alleged that military forces were aiding law enforcement by detaining him. But the United States District Court for the Southern District of New York did not see Padilla's detention as a law enforcement matter. It said:

Padilla is not being detained by the military in order to execute a civilian law or for violating a civilian law, notwithstanding that his alleged conduct may in fact violate one or more such laws. He is being detained in order to interrogate him about the unlawful organization with which he is said to be affiliated and with which the military is in active combat, and to prevent him from becoming reaffiliated with that organization. ${ }^{57}$

The court therefore found no violation of the Posse Comitatus Act. Again, characterization determined which legal regime applied to the governmental action.

The second incident involved a pair of snipers who terrorized the District of Columbia, Maryland, and Virginia in 2002. John Muhammad and Lee Malvo drove through suburban areas, with one or both of them shooting people at random through a hole they had made in the trunk of their car. ${ }^{58}$ The attacks went on for weeks, with 11 persons shot and thousands terrified. Muhammad and Malvo never made their aims fully clear, although they did ask for money at one point. $^{59}$

In an effort to apprehend the snipers, the FBI requested assistance from the Department of Defense. ${ }^{60}$ The Department of Defense responded by providing an Army surveillance airplane. ${ }^{61}$ The aircraft had the ability to cover a large area and to use special electronic equipment to detect the heat and sound of small arms fire, possibly including shots fired by the

\footnotetext{
${ }^{56}$ See Padilla ex rel. Newman v. Bush, 233 F. Supp.2d 564, 588 n.9 (S.D.N.Y. 2002), rev'd on other grounds sub nom. Padilla v. Rumsfeld, 352 F.3d 595 (2d Cir. 2003), rev'd on other grounds, 542 U.S. 426 (2004).

${ }^{57} \mathrm{Id}$.

${ }^{58}$ See Adam Liptak, Teenage Sniper to Plead Guilty in Two Shootings, N.Y. TIMES, Sept. 24, 2004, at A10.

${ }^{59}$ See Carol Morello, Victims' Relatives Still Ask, “Why? ”; Snipers' Motives Remain Unresolved, WASH. Post, Mar. 11, 2004, at A11.

${ }^{60}$ DoD News Briefing, Sec'y of Defense Donald Rumsfeld and Gen. Richard Myers, Oct. 17, 2002, available at $<$ http://www.defenselink.mil/transcripts/2002/t10172002_t1017sd.html $>$ [hereinafter DoD Sniper Briefing].
} 
snipers from their rifle. ${ }^{62}$ If the Department of Defense could provide instantaneous information about the location of gun shots across the area, the FBI hoped that it could locate and apprehend the snipers. ${ }^{63}$

Critics argued that the surveillance activity violated the Posse Comitatus Act because it was a form of military assistance to law enforcement. ${ }^{64}$ But others disagreed; some supporters of the plan said that the Posse Comitatus Act does not prevent the military from engaging in "passive" support to law enforcement. ${ }^{65}$ When asked at a Press Conference about the legality of the Army's assistance to the FBI, Secretary of Defense Donald Rumsfeld simply said: "We have looked at our assets and capabilities and tried to determine what we might do to be of assistance to them that's consistent with the law, the Posse Comitatus law.... We do know that what we're doing is fully consistent with the law, full stop." ${ }^{.66}$ Secretary Rumsfeld also likened the action to "combat air patrols flying, looking for airplanes that might crash into the White House or the Capitol or the Pentagon or the World Trade Center." ${ }^{97}$ He said that military forces can prevent a "bad act" and "it's not quite law enforcement." 68

Thus, again, rather than attempting to view military responses to terrorism as a separate category, and to determine what rules should apply to that category, the disputants contested whether the responses should be viewed either as a law enforcement measure or as military actions taken in an armed conflict.

\footnotetext{
${ }^{61}$ See Tom Bowman et al., Spy Planes to Hunt Sniper, BALtimore Sun, Oct. 16, 2002, at 1A.

${ }^{62}$ See Steve Vogel, Military Aircraft With Detection Gear To Augment Police, WASH. Post, Oct. 16, 2002, at A1.

${ }^{63}$ See id.

${ }^{64}$ See Fred Kaplan \& Lyle Denniston, Army Plane Joins Sniper Hunt: Some Question Use of Surveillance Craft, Boston Globe, Oct. 17, 2002, at A1; Adam Clymer, Big Brother Joins Hunt for the Sniper, N.Y. TiMES, Oct. 20, $2002, \S 4$, at $3 \ldots$

${ }^{65}$ See Kaplan \& Denniston, supra note 64, at A1.

${ }^{66}$ DoD Sniper Briefing, supra note 60.

${ }^{67} \mathrm{Id}$.
} 
The United States is not alone in debating this kind of issue. In 1995, the Russian Constitutional Court had to decide whether Russia's constitution banned the use of military forces against Chechen rebels. ${ }^{69}$ The Russian Federation was using military force pursuant to decrees issued by President Yeltsin and pursuant to resolutions of the State Duma (which is the lower house of Russia's bicameral parliament). ${ }^{70}$ The Federation Council of the Russian Federation (which is the upper chamber of the parliament) and other plaintiffs challenged this domestic use of military force in the Russian Constitutional Court. ${ }^{71}$

The Federation Council argued that the use of armed forces in Russia's territory under Russia's constitution is only permitted if the Federal Council declares a state of emergency or martial law. ${ }^{72}$ In other words, the Federation Council argued that military measures could not be used because there was no recognized armed conflict. Presumably, the Federation Council believed that the Russian government could use only conventional law enforcement techniques to address the situation. But the Constitutional Court upheld the use of force. ${ }^{73}$ It rejected the idea that only law enforcement agencies could respond to the crisis. The court noted that the Duma had concluded that "the disarmament of the unlawful armed militia raised in that republic, which were using tanks, missile launchers, artillery systems and war planes, 'was impossible in principle without the use of regular troops.",74 The court thus saw the situation more like an armed conflict.

\footnotetext{
${ }^{68} i d$.

${ }^{69}$ See Judgment of the Constitutional Court of the Russian Federation on the constitutionality of the Presidential Decrees and the Resolutions of the Federal Government concerning the situation in Chechnya (1995) (available at http://ks.rfnet.ru/english/decision/d310795e.htm>).

${ }^{70}$ See id. 11.

${ }^{71}$ See id.

${ }^{72}$ See id.

${ }^{73}$ See id. 96.

${ }^{74}$ Id.
} 
Once again, what neither side in the dispute considered was the possibility that counterterrorism measures might fall into a separate category. They appeared to view the question simply as whether terrorism amounted to an armed conflict or instead was just a matter for criminal law enforcement. They did not recognize the possibility that terrorism may lie somewhere in between war and crime, and that separate rules should determine the permissibility of particular responses to terrorism.

\section{C. $\quad$ Targeted Killing}

Targeted killing is the practice of shooting or using bombs or other methods to kill suspected terrorists without attempting to arrest them. The United States has used this counterterrorism measure a number of times. In June 2006, the United States killed the al-Qaida leader in Iraq, Abu Musab al-Zarqawi, by dropping two 500-pound bombs on what al-Zarqawi thought was a safe-house. ${ }^{75}$ In January 2005 , the United States attempted to kill Ayman alZawahiri, reputedly Osama bin Laden's chief lieutenant, by destroying a house in Pakistan. ${ }^{76}$ As it turned out, Al-Zawahiri was not in the building, but the strike killed other suspected terrorists (as well a large number of women and children). ${ }^{77}$ In December 2004, the United States killed al-Qaida operations chief Hamza Rabia with a missile near the Afghanistan and Pakistan border. $^{78}$ In November 2002, the United States fired a missile at and killed Qaed Salim Sinan alHarethi, one of the masterminds of the bombing of the U.S.S. Cole as he was riding in a car in

\footnotetext{
${ }^{75}$ See John F. Burns et al., After Long Hunt, U.S. Bombs Kill Al Qaeda Leader in Iraq, N.Y. TimES, Jun. 9, 2006, at 1.

${ }^{76}$ See Carlotta Gall et al., U.S. Raid Killed Qaeda Leaders, Pakistanis Say, N.Y. TIMES, Jan. 19, 2006, at A1.

${ }^{77}$ See id.

${ }^{78}$ See Mohammad Khan \& Douglas Jehl, Attack Kills A Top Leader Of Al Qaeda, Pakistan Says, N.Y. TimES, Dec. 4, 2005, at sec. 1, p. 24.
} 
Yemen. ${ }^{79}$ In fact, these five incidents actually represent only a small fraction of the total number of suspected terrorists targeted by the United States. The Los Angeles Times reported in January 2006 that "the United States is expanding a top-secret effort to kill suspected terrorists with drone-fired missiles as it pursues an increasingly decentralized Al Qaeda." ${ }^{\text {}}$ The details concerning the number of strikes apparently are classified, but the reporter counted a total of 19 separate targeted killings that have occurred so far.

Other nations also have used targeted killing to dispense with suspected terrorists. Russia, as mentioned above, reportedly sent a poison letter to the person suspected of masterminding the 2000 Moscow apartment bombing. ${ }^{81}$ Israel has killed scores of suspected members of Hamas, using everything from helicopter gunships to exploding cell phones. ${ }^{82}$

A basic question is whether the targeted killing of suspected terrorists is lawful. At present, the answer, like so many answers, depends on whether the action is viewed as a law enforcement measure or as a step taken in an armed conflict. In general, the police cannot simply kill criminal suspects, but instead must arrest them. In contrast, the military usually can kill enemy combatants without attempting to arrest them unless they already have surrendered.

Consider first the rules regarding law enforcement. In the United States, the Fifth Amendment plainly says: "No person shall . . be deprived of life, liberty, or property, without due process of law ....,"83 And the Fourth Amendment similarly prohibits "unreasonable"

\footnotetext{
${ }^{79}$ See James Resin \& Judith Miller, C.I.A. Is Reported to Kill a Leader of Gaeda in Yemen, N.Y. TIMES, Nov. 5, 2002, at A1.

${ }^{80}$ Josh Meyer, CIA Expands Use of Drones in Terror War, L.A. TIMES, Jan. 29, 2006, at A1.

${ }^{81}$ See Baker, supra note 15 , at A13.

${ }^{82}$ Between 2000 and mid-2003, the Israeli government reportedly engaged in the targeted killing of about 150 Palestinian militants. See Molly Moore, Israel's Lethal Weapon of Choice: As Assassinations of Militants Increase, Citizens' Uneasiness Grows, Wash. Post., Jul. 29, 2003, at A1.

${ }^{83}$ U.S. Const. amend. 5.
} 
searches and seizures. ${ }^{84}$ Based on these provisions, our courts have held that a police officer may not "seize an unarmed, nondangerous suspect by shooting him dead." ${ }^{85}$ Instead, the police are supposed to arrest suspects so that courts may determine their innocence or guilt and rule on their punishment.

Multilateral treaties embody similar protections. The International Covenant on Civil and Political Rights, which the United States and most other nations have ratified, says: "Every human being has the inherent right to life. This right shall be protected by law. No one shall be arbitrarily deprived of his life." ${ }^{\prime 86}$ The European Convention on Human Rights says: "Everyone's right to life shall be protected by law. No one shall be deprived of his life intentionally save in the execution of a sentence of a court following his conviction of a crime for which this penalty is provided by law." ${ }^{87}$ The European Convention contains exceptions allowing the police to kill criminal suspects, but only "in order to effect a lawful arrest or to prevent escape of a person lawfully detained." 88

The United Nations Basic Principles on the Use of Force and Firearms by Law Enforcement Officials addresses the subject in detail. ${ }^{89}$ Article 9 says that "intentional lethal use of firearms may only be made when strictly unavoidable in order to protect life." ${ }^{, 90}$ Article 10 further says that "law enforcement officials shall identify themselves as such and shall give a

\footnotetext{
${ }^{84}$ See id. amend. 4.

${ }^{85}$ See Tennessee v. Garner, 471 U.S. 1, 11 (1985).

${ }^{86}$ International Covenant on Civil and Political Rights, art. 6, G.A. Res. 2200, U.N. GAOR, 21 st Sess., Supp. No. 16, at 53, U.N. Doc. A/6316 (1966) [hereinafter ICCPR].

${ }^{87}$ Convention for the Protection of Human Rights and Fundamental Freedoms art. 2, opened for signature Nov. 4, 1950, preamble, 213 U.N.T.S. 222 (Council of Europe) (entered into force Sept. 3, 1953) [hereinafter European Convention].

${ }^{88} I d$. art. 2(2)(b).

${ }^{89}$ Basic Principles on the Use of Force and Firearms by Law Enforcement Officials, UN Doc. A/CONF.144/28/Rev.1, at 112, para. 9 (1990), available at $<\mathrm{http}: / /$ www.unhchr.ch/html/menu3/b/h_comp43.htm $>$ [hereinafter Basic Principles].
} 
clear warning of their intent to use firearms, with sufficient time for the warnings to be observed, unless to do so would unduly place the law enforcement officials at risk or would create a risk of death or serious harm to other persons ...." U1 Under all of these various rules, targeted killing of criminal suspects is illegal.

But the laws governing armed conflict are different. When military forces are fighting a war, they may attack enemy forces wherever they find them without affording them an opportunity to surrender. This has been the law for a long time. In the United States, the Lieber Code of 1863 (promulgated as a military order to govern Union Forces during the Civil War) famously declared: "Military necessity admits of all direct destruction of life or limb of armed enemies, and of other persons whose destruction is incidentally unavoidable in the armed contests of the war ...."92 Still today, military forces may kill enemy combatants who have not surrendered, ${ }^{93}$ and nothing in the law of armed conflict requires military forces to afford the enemy the opportunity to surrender before attacking them.

True, some prohibitions on assassination apply to the military. For example, the Annex to Hague Convention No. IV, Respecting the Laws and Customs of War on Land, says: "In addition to the prohibitions provided by special Conventions, it is especially forbidden ... [t]o kill or wound treacherously individuals belonging to the hostile nation or army ...."94 The U.S. Army interprets this provision "as prohibiting assassination, proscription, or outlawry of an

\footnotetext{
${ }^{90}$ Id. art. 9.

${ }^{91} I d$. art. 10.

${ }^{92}$ See Instructions for the Government of Armies of the United States in the Field, General Orders No. 100 , art. 15 (Apr. 24, 1963) (military order of President Lincoln implementing rules drafted by Francis Lieber, LL.D), available at $<$ http://www.yale.edu/lawweb/avalon/lieber.htm>.

93 See U.S. Army Field Manual 27-10, The Law of Land Warfare, ch. 2, sec. II, 129 (1956) (citing Annex to Hague Convention No. IV, Oct. 18, 1907, embodying the Regulations Respecting the Laws and Customs of War on Land, art. 23(c)).
} 
enemy, or putting a price upon an enemy's head, as well as offering a reward for an enemy 'dead or alive." 95 But the Army also says that the provision does not "preclude attacks on individual soldiers or officers of the enemy whether in the zone of hostilities, occupied territory, or elsewhere." 96 So under the U.S. view, military forces could kill suspected terrorists if they are enemy combatants.

A recent dispute illustrates how the categorization of targeting killing affects the analysis of its legality. In November 2002, as mentioned above, the United States used an unmanned Predator aircraft to attack a car in Yemen. ${ }^{97}$ The car was carrying six men, all of whom died in the attack. One of the men was Abu Ali al-Harethi, an al-Qaida member suspected of masterminding the October 2000 attack on the U.S.S. Cole in Yemen. ${ }^{98}$ Another one of the men in the car was an American citizen named Ahmed Hijazi. ${ }^{99}$ The United States and the government of Yemen worked together in planning and executing the attack. ${ }^{100}$

Subsequently, the United Nations Special Rapporteur on Extrajudicial, Summary or Arbitrary Executions wrote a letter to the United States asking the government to explain the incident and justify the killing of the men in the car. ${ }^{101}$ The letter referred to the provisions of

\footnotetext{
${ }^{94}$ Annex to Hague Convention No. IV, embodying the Regulations Respecting the Laws and Customs of War on Land, art. 23(c) (Oct. 18, 1907).

${ }_{95}$ See U.S. Army Field Manual 27-10, supra note 93, ch. 2, sec. II, $₫ 31$.

${ }^{96} \mathrm{Id}$.

${ }^{97}$ See Reuters, supra note 13 , at A21.

${ }^{98}$ See Michael Powell \& Dana Priest, U.S. Citizen Killed by CIA Linked to N.Y. Terror Case, WASH. Post, at A1 (Nov. 9, 2002).

${ }^{99}$ See id.

${ }^{100}$ See id.

${ }^{101}$ Report of the Special Rapporteur on Extrajudicial, Summary or Arbitrary Executions, Asma Jahangir: Addendum, Summary of Cases Transmitted to Governments and Replies Received, qণ 611-613, E/CN.4/2004/7/Add.1 (March 24, 2004), available at $<$ http://www.unhchr.ch/huridocda/huridoca.nsf/AllSymbols/77B55485D5D112BBC1256E67004EADA3/\$File/G04 12275.pdf?OpenElement>.
} 
the International Covenant on Civil and Political Rights quoted above. ${ }^{102}$ In the letter, the Special Rapporteur said that the action "constitutes a clear case of extrajudicial killing.", 103 In other words, the Special Rapporteur saw the incident as an impermissible method of law enforcement.

The United States had a different view. It saw the military action not as a law enforcement measure, but instead as a method of fighting a war against an armed enemy. In its response, the United States said: "The United States . . . disagrees with the premise of the letter and the conclusions contained in the report that military operations against enemy combatants could be regarded as "extrajudicial executions by consent of Governments.",104 In its view, the "conduct of a government in legitimate military operations, whether against Al Qaida operatives or any other legitimate military target, would be governed by the international law of armed conflict." "105 Under that law, the United States said, "enemy combatants may be attacked unless they have surrendered or are otherwise rendered hors de combat."106 Accordingly, the United States concluded, “Al Qaida terrorists who continue to plot attacks against the United States may be lawful subjects of armed attack in appropriate circumstances."

\section{Detention}

\footnotetext{
${ }^{102}$ See Letter from Jeffrey De Laurentis, Chief of Section, Political and Specialized Agencies of the Permanent Mission of the United States of America to the United Nations Office at Geneva, to the secretariat of the Commission on Human Rights at 1 (April 14, 2003) [hereinafter U.S. Yemen Response] (describing the Special Rapporteur's letter), available at $<$ http://www.unhchr.ch/Huridocda/Huridoca.nsf/e06a5300f90fa0238025668700518ca4/9b67b6687466cfcac1256d2 600514c7f/\$FILE/G0313804.pdf>.

${ }^{103} \mathrm{Id}$.

${ }^{104}$ See id.

105 Id. at 5.

${ }^{106}$ Id. Hors de combat means "out of the fight." The term usually refers to combatants who have become disabled by injury or illness.
} 
The rules that govern the detention of criminal suspects differ from the rules that govern the detention of enemy combatants. For this reason, the characterization of persons held as terrorists often is very important. If these persons are viewed as criminal suspects, they generally have greater rights than if they are viewed as enemy combatants in an armed conflict. Under the domestic law of the United States, law enforcement agencies generally may detain criminal suspects only for the purpose of bringing them before a court for trial. ${ }^{108}$ Suspects are entitled to appear before a magistrate without unreasonable delay after they are arrested. ${ }^{109}$ This magistrate must order them released if probable cause does not exist to believe that they have committed a crime. ${ }^{110}$ Even if probable cause does exist, the suspects then have a right to a speedy trial. ${ }^{111}$ If they do not receive a speedy trial, they are entitled to dismissal of any indictment and to release. ${ }^{112}$

Similar rules govern law enforcement outside the United States. For example, article 5 of the European Convention on Human Rights provides: "No one shall be deprived of his liberty save in the following cases and in accordance with a procedure prescribed by law: ... (c) the

\footnotetext{
${ }^{107} I d$.

${ }^{108}$ See Zadvydas v. Davis, 533 U.S. 678, 690 (2001) (ordinarily "government detention violates [the Due Process] Clause unless the detention is ordered in a criminal proceeding with adequate procedural protections").

${ }^{109}$ See Fed. R. Crim. P. 5(a)(1)(A) ("A person making an arrest within the United States must take the defendant without unnecessary delay before a magistrate judge, or before a state or local judicial officer . . unless a statute provides otherwise.”); County of Riverside v. McLaughlin, 500 U.S. 44, 57 (1991) (requiring probable cause hearing or arraignment within 48 hours of arrest).

${ }_{110}^{110}$ See Fed. R. Crim. P. 5(b).

${ }^{111}$ See U.S. Const. amend. 6 ("In all criminal prosecutions, the accused shall enjoy the right to a speedy and public trial ....”); 18 U.S.C. $\S 3161(\mathrm{c})(1)$ (ordinarily providing a right to a trial within 70 days after the defendants first appears before a judicial officer).

${ }^{112}$ See Fed. R. Crim. P. 48(b)(3) (permitting dismissal of indictment for unreasonable delay in bringing a defendant to trial); 18 U.S.C. § 3164(c) ("No detainee .... shall be held in custody pending trial after the expiration of [the Speedy Trial Act's] ninety-day period required for the commencement of his trial.").
} 
lawful arrest or detention of a person effected for the purpose of bringing him before the competent legal authority on reasonable suspicion of having committed an offence . ..."113

But the law of armed conflict differs in several very important ways when it comes to questions of detention. The law of armed conflict contemplates that in a war, a nation may need to capture numerous enemy combatants and may need to hold them for many years. The United States, for example, imprisoned hundreds of thousands of captured German, Italian, and Japanese soldiers during World War II. ${ }^{114}$ Although litigants and commentators recently have disputed some of these points, the following rules appear to apply to the detention of enemy combatants:

First, the law of armed conflict apparently permits a government to detain all enemy belligerents regardless of whether they have committed any crimes. In Hamdi v. Rumsfeld, a plurality of the Supreme Court concluded that the "capture and detention of lawful combatants and the capture, detention, and trial of unlawful combatants, by 'universal agreement and practice,' are 'important incident[s] of war.",115 Justice Thomas, a fifth vote for this proposition, agreed that the government may detain captured belligerents without charges. ${ }^{116}$ This rule apparently applies regardless of the location in which the government captured the belligerent or whether the belligerent is a United States citizen. ${ }^{117}$

Second, the government apparently needs to follow only minimal procedures for initially determining who is an enemy combatant and who is not. These procedures apparently may place

\footnotetext{
${ }^{113}$ European Convention, supra note 87, art. 5.

${ }^{114}$ See Curtis A. Bradley \& Jack L. Goldsmith, Congressional Authorization and the War on Terrorism, 118 HARV. L. REV. 2047, 2106 n.271 (2005).

${ }^{115} 542$ U.S. 507, 518 (O’Connor, J.) (plurality opinion) (quoting Ex parte Quirin, 317 U.S. 1, 28 (1942)).

${ }^{116}$ See id. at 589 (Thomas, J., dissenting) ("I agree with the plurality that the Federal Government has power to detain those that the Executive Branch determines to be enemy combatants.")

${ }^{117}$ Padilla v. Hanft, 423 F.3d at 390 (interpreting Hamdi).
} 
the burden of proof on the detainee. ${ }^{118}$ They may establish a presumption in favor of the government's evidence even if the evidence is based on hearsay. ${ }^{119}$ The government apparently also does not have to afford the detainee the right to counsel. ${ }^{120}$

Third, if the military determines that a person is a belligerent, it may detain him at least for the duration of the conflict in which he was captured. ${ }^{121}$ This rule allowed the United States to hold German, Italian, and Japanese prisoners in World War II until the hostilities ceased. The government does not have to release all detainees when the war ends; on the contrary, if the government convicts a detainee of war crimes, it may also imprison him or her as sentenced by a court just like any other criminal suspect.

As a result of these rules, suspected terrorists face very different treatment depending on whether they are viewed as criminal suspects or instead as enemy combatants. So naturally many debates have arisen over how to characterize suspected terrorists. An ongoing example of this debate concerns persons whom the United States has detained in its war on terror.

Consider again the case of Jose Padilla, the American citizen who fought against the United States in Afghanistan and who was captured at O'Hare airport in Chicago. ${ }^{122}$ When Padilla challenged the legality of his confinement in a naval brig without charges, a debate

\footnotetext{
${ }^{118}$ See Hamdi, 542 U.S. at 534 (O’Connor, J.) (plurality opinion) (“[T]the Constitution would not be offended by a presumption in favor of the Government's evidence, so long as that presumption remained a rebuttable one and fair opportunity for rebuttal were provided.").

${ }^{119}$ See id. ("Hearsay, for example, may need to be accepted as the most reliable available evidence from the Government in such a proceeding.").

${ }^{120}$ The plurality opinion in Hamdi did not reach this issue because Hamdi had counsel. See id. at 539. The United States military traditionally has not afforded counsel to detainees who dispute their status as combatants. See Enemy Prisoners of War, Retained Personnel, Civilian Internees and Other Detainees, Army Regulation 190-8, § 1-6 (1997) (stating procedures for tribunals to use in deciding the status of persons detained in a conflict).

${ }^{121}$ See Hamdi, 542 U.S. at 518 (O'Connor, J.) (plurality opinion) (concluding that the United States may hold enemy combatants for the "duration of the relevant conflict").

${ }^{122}$ See supra part II.B.
} 
quickly arose over how to characterize him. The district court viewed Padilla as a criminal suspect. It said:

Simply stated, this is a law enforcement matter, not a military matter. The civilian authorities captured Petitioner just as they should have. At the time that Petitioner was arrested . . . any alleged terrorist plans that he harbored were thwarted. From then on, he was available to be questioned - and was indeed questioned - just like any other citizen accused of criminal conduct. This is as it should be. ${ }^{123}$

Because the government had not brought criminal charges against Padilla, the district court ordered Padilla released, just as it would order the release of any criminal suspect whom the government had not charged. ${ }^{124}$ The district court left open the possibility that the government could continue to hold Padilla if it were to bring criminal charges against him. ${ }^{125}$

Outside organizations agree with this characterization of terrorist suspects. Amnesty International, for example, has declared that the detention of suspected terrorists without charges by the United States is a "continuing violation of human rights standards which the international community must not ignore." 126 It has urged that "detainees should be charged with recognisably criminal offences and tried within a reasonable time, or released." ${ }^{\prime 27}$

But the Court of Appeals for the Fourth Circuit expressed a different view when it considered the Padilla case. It reversed the district court because it agreed that the President could characterize Padilla as an "enemy combatant" rather than as a mere criminal suspect. ${ }^{128}$

${ }^{123}$ See 389 F. Supp.2d 678, 691 (D.S.C. 2005).

${ }^{124}$ See id.

${ }^{125}$ See id. at 692, n. 14 .

${ }^{126}$ Amnesty International UK, USA: One Year On-The Legal Limbo of the Guantanamo Detainees Continues, $<\mathrm{http}: / / \mathrm{www}$.amnesty.org.uk/deliver?document $=14285>$.

${ }^{127} \mathrm{Id}$. One difficulty, rarely mentioned, is that many of the detainees do not want to be released because they would face far worse treatment in their home countries. Amnesty International therefore has urged the United States not to release anyone who would be "returned to any country where they would be at risk of torture, execution or other serious human rights abuses." Id.

${ }^{128} 423$ F.3d at 394-95. 
The court then held: "Because Padilla is an enemy combatant, and because his detention is . . necessary . . . in order to prevent his return to the battlefield, the President is authorized ... to detain Padilla as a fundamental incident to the conduct of war."129 The Supreme Court never resolved this issue because before it could review the decision, the United States obtained an indictment against Padilla and began treating him as an ordinary criminal suspect, thus mooting the question. $^{130}$

The debate about whether to characterize persons accused of terrorism as criminal suspects or enemy combatants in determining whether the government has the power to detain them is not confined to the United States. For example, nearly five decades ago, the Irish government held a man named Richard Lawless for several months without charges. ${ }^{131}$ It justified this detention on grounds that Lawless was suspected of belonging to the Irish Republican Army (IRA), an organization described as "a secret army engaged in unconstitutional activities and using violence to attain its purposes" 132 and blamed for an "alarming increase in terrorist activities." 133 The government contended that it needed to detain Lawless "to prevent the maintaining of military or armed forces other than those authorised by the Constitution."134 Thus, just as the United States saw Jose Padilla as an enemy combatant belonging to al-Qaida, the Irish government saw Lawless as a soldier for the IRA.

\footnotetext{
${ }^{129} \mathrm{Id}$. at 392.

${ }^{130}$ See Padilla v. C.T. Hanft, 126 S. Ct. 1649 (2006) (Kennedy, J., concurring denial of certiorari) (describing Padilla's classification and reclassification).

${ }^{131}$ Lawless v. Ireland, 1 Eur. Ct. H.R. 15 (1961).

${ }^{132}$ Id. $\Upsilon 28$.

${ }^{133} I d$.

${ }^{134}$ Id. $\ 43$.
} 
Lawless had a different view. He saw himself as a mere criminal suspect, and argued that his detention without charges violated article 5 of the European Convention on Human Rights. ${ }^{135}$ This provision as quoted above, prohibits arrests other than for the purpose of bringing a criminal suspect before a judge "on reasonable suspicion of having committed an offence . . ."136 Lawless argued that the Irish government had not brought him before a judge or asserted any charges against him. ${ }^{137}$

The European Court of Human Rights sided with Lawless's characterization, but it denied him any relief. It concluded that the detention was contrary to article 5 of the European Convention because the Irish government had not charged him with any offense. ${ }^{138}$ But it could offer no remedy because it concluded that the Irish government had followed the proper procedures for derogating from the European Human Rights Convention. ${ }^{139}$

\section{E. Trials}

Criminal suspects have many rights when they come to trial in civilian courts. In the United States, for example, the Fifth Amendment grants criminal suspects a general right to due process and a specific right not to be tried absent a grand jury indictment, ${ }^{140}$ and the Sixth Amendment affords them a right to have a speedy and public trial, to be tried by a jury, to be

\footnotetext{
${ }^{135} \mathrm{Id}$.

${ }^{136}$ European Convention, supra note 87, art. 5(1)(c).

${ }^{137}$ See 1 Eur. Ct. H.R. 15, ๆ 10-15.

${ }^{138}$ See id. 15.

${ }^{139}$ See id. 147 . The European Convention provides that "[i]n time of war or other public emergency threatening the life of the nation any High Contracting Party may take measures derogating from its obligations under this Convention to the extent strictly required by the exigencies of the situation ...." European Convention, supra note 87, at 15(1). But a nation must follow specific procedures to effect a derogation. See id. art. 15(3).

${ }^{140}$ U.S. Const. amend. 5.
} 
tried in the district where the crime occurred, and to confront the witnesses against them. ${ }^{141}$ And multilateral treaties also require the United States and other nations to provide important trial rights. For example, the International Covenant on Civil and Political Rights mandates that criminal suspects have a trial before an independent judge ${ }^{142}$ and appellate review by a separate appellate tribunal. ${ }^{143}$

In contrast, some enemy combatants do not have the same rights when they come to trial before a "military commission." A military commission is a tribunal consisting of a panel of military officers or a combination of military officers and civilians. ${ }^{144}$ The United States has used military commissions throughout its history to try persons accused of war crimes. ${ }^{145}$ During and immediately after World War II, for instance, allied forces used military commissions to try many German soldiers and civilians accused of war crimes. ${ }^{146}$ These war crimes included many different kinds of offenses, including the offense of fighting as an unlawful combatant. ${ }^{147}$

The Supreme Court has held that military commissions, absent contrary legislation, do not have to follow the same trial procedures that civilian criminal courts use. ${ }^{148}$ Military commissions, for example, need not provide persons suspected of war crimes with a trial by

\footnotetext{
${ }^{141}$ See id. amend. 6.

${ }^{142}$ See ICCPR, supra note 86, art. 14(1).

${ }^{143}$ See id. art. 15(4).

${ }^{144}$ See BLACK's LAW DICTIONARY, supra note 47, at 1013.

145 See William Winthrop, Military LAW AND PRECEDENTS 831-45 (2d ed. 1920) (discussing the history of military commissiones prior to World War II).

146 See MAGGS, supra note 1 , at 383 \& n.1 (2005) (describing these tribunals).

${ }^{147}$ See Ex Parte Quirin, 317 U.S. 1, 30-31 (1942).

${ }^{148}$ See Hamdan v. Rumsfeld, 126 S. Ct. 2749, 2788-91 (2006) (recognizing that the procedures of military commissions used in post-World War II military commission, established in a common law fashion, did not follow civilian or military procedures, but holding that Congress by statute now has mandated procedures military commission must follow).
} 
jury. ${ }^{149}$ They also do not have to state the charges against a suspect with the specificity of an ordinary criminal indictment. ${ }^{150}$

Because criminal suspects have different rights from enemy combatants, the now familiar debate over characterization arises when nations want to try persons accused of committing terrorist acts. One side of the debate argues that these persons should be characterized as criminal defendants and should have all of the rights that criminal defendants enjoy. The other side argues that they can be characterized as enemy combatants and given trials by military commission for committing war crimes, such as fighting as an unlawful combatant.

This debate has gone on for several years in the United States. In November 2001, shortly after the infamous attacks of September 11th, President Bush ordered the creation of military commissions to try foreign terror suspects now held at Guantanamo Bay, Cuba. ${ }^{151}$ This order described these suspects not as criminals but as persons engaged in an armed conflict against the United States. ${ }^{152}$ The order guaranteed them the right to a "full and fair" trial but did not guarantee them all the rights that criminal defendants in the United States would have. ${ }^{153}$ As a result, great controversy arose arisen over the legality of this counterterrorism measure. One of the detainees facing trial by military commission, Salim Ahmed Hamdan, argued before the Supreme Court that if he is accused of terrorist violence, he should be treated as a criminal

\footnotetext{
149 See id. at 44.

${ }^{150}$ See Application of Yamashita, 327 U.S. 1, 17 (1946).

${ }^{151}$ Military Order of November 13, 2001, Detention, Treatment, and Trial of Certain Non-Citizens in the War Against Terrorism, 66 Fed. Reg. 57833 (Nov. 13, 2001).

${ }^{152}$ See id. $\$ 1(\mathrm{a})$.

${ }^{153}$ See id. § 4(c)(2).
} 
suspect and charged in a federal civilian court. ${ }^{154}$ The government, in contrast, contended that he was an enemy combatant, and that a military trial therefore could charge him. ${ }^{155}$

The Supreme Court avoided resolving the basic question of characterization raised in this debate. In Hamdan v. Rumsfeld, the Court held that even if Hamdan was an enemy combatant and could be tried by a military commission, the President had improperly constituted the military commissions at Guantanamo. The Court ruled that procedural and evidentiary rules violated a provision of the Uniform Code of Military Justice which it interpreted to require the rules of military commissions to be uniform with the rules of courts-martial unless the President finds uniformity impracticable. ${ }^{156}$ (As explained below, Congress has responded by enacted a new law to govern military commissions. ${ }^{157}$ )

The European Court of Human Rights has confronted a similar question of characterization. During the 1990s, Turkey used the Ankara State Security Court to try persons suspected of terrorism. ${ }^{158}$ This court was not called a military commission but it resembled one because it included a military officer as one of its judges. ${ }^{159}$ In 1994, this special court convicted Selim Sadak and several others of terrorist offenses in connection with their support for the banned Kurdish Workers Party. ${ }^{160}$ Sadak and the others subsequently sued Turkey in the

\footnotetext{
${ }^{154}$ See Brief for Petitioner Salim Ahmed Hamdan, Hamdan v. Rumsfeld, 2006 W.L. 53988, *9 (Jan. 6. 2006).

${ }^{155}$ See Brief for Respondents, Hamdan v. Rumsfeld, 2006 WL 460875, *28-29 (Feb. 23, 2006).

${ }^{156}$ See Hamdan, 126 S. Ct. 2749, 2790-91. Section 36(a) of the Uniform Code of Military Justice gives the President authority to promulgate rules of evidence and procedures for various military tribunals including courtsmartial and military commissions. 10 U.S.C. $\S 836(\mathrm{a})$. But $\S 36(\mathrm{~b})$ requires all rules promulgated to "be uniform in sofar as practicable." Id. $\S 836(\mathrm{~b})$. The Supreme Court interpreted the term "uniform" in $\S 36$ (b) to mean that rules for different types of tribunals must be uniform; it did not consider the more plausible interpretation that the word meant that the rules for each type of tribunal must be uniform for each armed service (e.g., the Army, Navy, Air Force, etc.).

${ }^{157}$ See infra part IV.D.

158 See Sadak v. Turkey, 36 Eur. Ct. H.R. 26, ๆๆ 39-40 (2003).

${ }^{159}$ See id.

${ }^{160}$ See id. \16.
} 
European Court of Human Rights, claiming that the inclusion of a military officer on the Ankara State Security Court violated the European Convention on Human Rights. ${ }^{161}$

The European Court of Human Rights agreed. In its view, Turkey had not given Sadak and the other applicants the rights owed to criminal defendants. ${ }^{162}$ Article 6 of the European Convention provides that "[i]n the determination of . . any criminal charge against him, everyone is entitled to a fair ... hearing . . . by an independent and impartial tribunal ...." The Court concluded that the military officer, although trained as a judge, would feel pressure to convict the accused to satisfy the government, and thus that the court lacked impartiality. ${ }^{163}$ Turkey had disagreed with the characterization of Sadak and the others as mere criminals. It argued that the nation was engaged in a military campaign against terrorism. "In view of the experience of the armed forces in the anti-terrorism campaign," the Turkish government explained, it "had considered it necessary to strengthen [the Ankara State Security Court] by including a military judge in order to provide the court with the necessary expertise and knowledge of how to deal with threats to the security and integrity of the State." 164

Yet another example comes from Egypt. Throughout the 1990s, Egypt used military courts to try militants suspected of threatening the government with terrorist acts. Egypt has contended that these military courts are necessary for dealing with armed combatants. ${ }^{165}$ Human rights groups, however, contend that they violate international standards for the treatment of criminal suspects. ${ }^{166}$

\footnotetext{
${ }^{161}$ See id. ๆ $39-40$.

162 See id.

${ }^{163}$ See id. $\uparrow \uparrow$ 39-40.

${ }^{164}$ Id. id. $₫ 34$.

165 See Associated Press, supra note 6, at 12.

${ }^{166}$ See id.
} 


\section{F. $\quad$ Search and Seizure}

The issue of whether to characterize counterterrorism measures as law enforcement or military action arises in the context of search and seizure by the government. The characterization matters because criminal suspects have rights to privacy that enemy combatants traditionally have not had. For example, in the criminal law context, the Fourth Amendment imposes an important restriction on law enforcement activity by requiring that searches and seizures be reasonable. ${ }^{167}$ The Supreme Court has held that a "search or seizure is ordinarily unreasonable in the absence of individualized suspicion of wrongdoing." ${ }^{168}$ So the police cannot simply seize and search any homes, cars, and places of business merely in the hopes of finding evidence of criminal activity.

In contrast, when the military is fighting a war, it does not face similar constraints. The Supreme Court has held that the constitutional power to declare war necessarily "involves the power to prosecute it by all means and in any manner in which war may be legitimately prosecuted."169 Accordingly, the Court has reasoned, the federal government's war power "includes the right to seize and confiscate all property of an enemy and to dispose of it at the will of the captor."170 Indeed, the Court said: "This is and always has been an undoubted belligerent right.",171

\footnotetext{
${ }^{167}$ See U.S. Const. amend. 4 ("The right of the people to be secure in their persons, houses, papers, and effects, against unreasonable searches and seizures, shall not be violated ....").

${ }_{168}^{168}$ City of Indianapolis v. Edmond, 531 U.S. 32, 37 (2000).

${ }^{169}$ Miller v. United States, 78 U.S. (11 Wall.) 268, 305 (1870).

${ }^{170} \mathrm{Id}$.

${ }^{171} I d$.
} 
These two differing sets of rules again lead to characterization disputes. In American Civil Liberties Union v. National Security Agency, ${ }^{172}$ the ACLU challenged a secret surveillance program. The National Security Agency, at the direction of the President, secretly listened to telephone calls between persons in the United States and suspected members of al-Qaida. The ACLU argued that the program violated the Fourth Amendment, analogizing it to eavesdropping on persons during a criminal investigation without a warrant. ${ }^{173}$ But the United States argued that it was a proper exercise of military force not addressed by the Fourth Amendment. ${ }^{174}$ The district court sided with the ACLU on this question of characterization (although the litigation continues). According to the district court, although Congress authorized the President to use "all necessary and appropriate force" against the persons responsible for the attacks of September 11, 2001, this authorization "says nothing whatsoever of intelligence or surveillance." 175 Therefore, in the court's view, the President could not lawfully be exercising military force. ${ }^{176}$

Another example of a disagreement over characterization occurred in United States v. Green. ${ }^{177}$ A woman named Green drove her car on a major road in San Antonio, Texas. ${ }^{178}$ The road passed through Fort Sam Houston, an open military reservation through which the public could drive. ${ }^{179}$ On the road, within the boundaries of the reservation, the post's military police

\footnotetext{
172438 F. Supp.2d 754 (E.D. Mich. 2006)

${ }^{173}$ See Plaintiffs' Motion for Partial Summary Judgment, ACLU v. NSA, 2006 WL 1868159 (May 9, 2006).

${ }^{174}$ See Memorandum of Points and Authorities in Support of the United States' Assertion of the Military and State Secrets Privilege; Defendants' Motion to Dismiss or, in the alternative, for Summary Judgment; and Defendants' Motion to Stay Consideration of Plaintiffs' Motion for Summary Judgment, ACLU v. NSA, 2006 WL 1868156 (May 26, 2006).

175438 F. Supp.2d at 779.

176 See id.

177293 F.3d 855 (5th Cir. 2002).

${ }^{178}$ See id. at 856-57.

${ }^{179}$ See id. at 861.
} 
had set up a check point. ${ }^{180}$ At this check point, the military police were stopping every sixth car to search for terrorists, as a means of deterring terrorism. ${ }^{181}$ Pursuant to this policy, the military police stopped Green's car. In the car, they found cocaine, and then arrested Green. ${ }^{182}$

Green argued that this suspicionless stop violated the Fourth Amendment. Citing the rules summarized above, the court agreed that the search would have been unconstitutional if the military police had simply been searching for criminals or trying to prevent general criminal activity. ${ }^{183}$ But the court held that the Fourth Amendment does not prohibit searches conducted by the military when it is engaged in "the protection of the nation's military installations from acts of domestic or international terrorism." 184 The court reasoned that looking for terrorists on a military reservation was more like this traditional military function than like criminal law enforcement. ${ }^{185}$ As a result of the court's characterizing the stop as a military action against terrorism instead of a law enforcement measure, Green could not rely on the protection of the Fourth Amendment.

A similar situation arose in the European Court of Human Rights in Murray v. United Kingdom. ${ }^{186}$ The British Army went to the home of Murray to arrest her and question her about suspected terrorist activities, including financing the procurement of arms for the IRA. ${ }^{187}$ Upon entering the home, they searched it for other occupants, and made Murray's family gather in one

\footnotetext{
${ }^{180}$ See id. at $856-857$.

${ }^{181}$ See id. at 858. The military police were following the "Standard Operating Procedure for the Installation Force Protection Vehicle Checkpoints." Id. This document identified listed "protect[ing] national security by deterring domestic and foreign acts of terrorism" as the first goal of checkpoint stops. Id.

${ }^{182}$ See id. at 857.

${ }^{183}$ See id. at 858 (citing City of Indianapolis v. Edmond, 531 U.S. 32 (2000), and other decisions).

${ }^{184}$ See id. at 859.

${ }^{185}$ See id.

18619 Eur. Ct. H.R. 193 (1995).

${ }^{187}$ See id. 11.
} 
room. ${ }^{188}$ Murray and her family challenged the army's action under article 8 of the European Convention. ${ }^{189}$ This article, which resembles the Fourth Amendment, provides that "[e]veryone has the right to respect for his private and family life, his home and his correspondence" and it generally prohibits interference with this right except when "necessary" for law enforcement, public safety, and other purposes. ${ }^{190}$ But the court disagreed, observing that this was not an ordinary law enforcement measure but instead a military security action. Citing the "responsibility of an elected government in a democratic society to protect its citizens and its institutions against the threats posed by organised terrorism and to the special problems involved in the arrest and detention of persons suspected of terrorist-linked offences" the court found the army's actions to satisfy article 8's requirement of "necessity."191 So again, because the incident was viewed as a military response rather than a law enforcement measure, Murray had different rights from those an ordinary criminal suspect would have.

\section{G. Duty to Provide Security}

The issue of whether to characterize counterterrorism responses as law enforcement or military action also arises in debates about the government's duty to provide security to potential victims of terrorism. At least as an abstract matter, governments have a duty both to prevent and punish crime and to protect their citizens from armed attacks. The preamble to the Constitution,

\footnotetext{
${ }^{188}$ See id. at $\uparrow 12$.

189 See id. 1 \ 83-95.

${ }^{190}$ European Convention, supra note 87, art. 8(1) \& (2).

19119 Eur. Ct. H.R. 193, ๆ 91.
} 
for example, identifies insuring "domestic tranquility" and providing for the "common defense" as two main objects of the federal government. ${ }^{192}$

But these abstract duties are not necessarily enforceable in the courts. On the contrary, both in the United States and in foreign countries, the judiciary has shown a greater willingness to intercede into law enforcement matters than into military affairs. Accordingly, potential victims of terrorism may have a greater ability to obtain a judicial order directing the government to take actions against terrorism if terrorists are seen as criminals than if they are seen as enemy combatants.

Consider, for example, the case of A. v. United Kingdom \& Ireland. ${ }^{193}$ The case arose after IRA terrorists killed a reserve constable in Northern Ireland while he was tending to his family's dairy business. ${ }^{194}$ The decedent's widow sued the United Kingdom in the European Court of Human Rights, claiming that the United Kingdom was violating article 2(1) of the European Convention on Human Rights. ${ }^{195}$ This article mandates that everyone's right to life "shall be protected by law."196 She asserted that the United Kingdom was not doing enough to provide security and demanded greater military involvement in the anti-terrorism campaign. She asked the court to require the United Kingdom to provide greater security from terrorist attacks "not only by criminal prosecution of offenders but also by such preventive control, through deployment of its armed forces, as appears necessary . . . ",197

\footnotetext{
${ }^{192}$ See U.S. Const. pream.

1938 Eur. Comm'n H.R. 49 (1986).

${ }^{194}$ See id.

195 See id. \17.

${ }^{196}$ European Convention, supra note 87, art. 2(1).

1978 Eur. Comm'n H.R. 49, 917.
} 
The European Commission on Human Rights, which handled the case for the court, ${ }^{198}$ ruled against her. To the extent that the terrorists were seen as an enemy threat requiring a military response, the commission concluded that it could not act. The commission observed that the United Kingdom had committed military forces to Northern Ireland, ${ }^{199}$ but the commission said that it could not be "its task" to assess the "appropriateness and efficiency" of this military force. ${ }^{200}$

In contrast, the commission apparently saw no difficulty in judging the United Kingdom's counterterrorism law enforcement effort. It agreed that the United Kingdom had a duty to provide security against murder. ${ }^{201}$ But it concluded that the applicant had no claim. The commission observed that "the applicant does not suggest that there are no laws in Northern Ireland protecting the right to life, or that they are not applied.",202

Plaintiffs have had similar difficulty recovering from the United States for not providing security against terrorism. Sovereign immunity generally shields the federal government from liability in court. ${ }^{203}$ The United States has waived some of its sovereign immunity in the Federal Tort Claims Act. ${ }^{204}$ But it has retained immunity from lawsuits pertaining to a "discretionary function."205

\footnotetext{
${ }^{198}$ Prior to 1998, the European Commission on Human Rights heard complaints concerning violations of the European Convention on Human Rights. If the Commission could not produce a settlement, it would prepare a report establishing the facts and expressing an opinion on the merits of the case. The European Court of Human Right then could consider the case. See European Court of Human Rights, Historical Background $<$ http://www.echr.coe.int/ECHR/EN/Header/The+Court/The+Court/History+of+the+Court/>

${ }^{199}$ See 8 Eur. Comm'n H.R. 49, ๆ 20.

${ }^{200} \mathrm{Id}$ ๑ 19.

${ }^{201}$ See id. $\uparrow 16$.

${ }^{202} I d$.

${ }^{203}$ See United States v. Mitchell, 463 U.S. 206, 212 (1983) ("It is axiomatic that the United States may not be sued without its consent and that the existence of consent is a prerequisite for jurisdiction.").

${ }^{204}$ See 28 U.S.C. $§ 1346$ (a)(2) (granting federal district courts jurisdiction over lawsuits "against the United States, not exceeding \$10,000 in amount, founded either upon the Constitution, or any Act of Congress, or any regulation of
} 
The retention of immunity for discretionary functions generally blocks claims against the United States for failing to provide protection against armed attacks. For example, in Macharia v. United States, plaintiffs injured by the 1998 terrorist bombing of the United States embassy in Kenya sued the United States for failing to secure the embassy against a terrorist attack. ${ }^{206}$ The United States had provided a detachment of Marines to guard the facility, but they had not succeeded in stopping a bombing by agents of al-Qaida. ${ }^{207}$ The court did not determine whether the United States had acted negligently because it held that the discretionary function exception to the Federal Tort Claims Act applied, and that the United States was therefore immune from liability. $^{208}$

But the discretionary function exception does not always shield the federal government from liability for failing to protect its citizens from terrorists when those acts are viewed as crimes. For example, in Bergman v. United States, ${ }^{209}$ the plaintiffs participated in the "Freedom Rides" of $1961 .^{210}$ They rode buses to cities in the southern United States to protest segregation. Unknown assailants subjected them to terror, assaults, and intimidation, causing various injuries. $^{211}$ The plaintiffs claimed in part that the FBI had negligently failed to protect them from the attacks that they endured. ${ }^{212}$ The federal government in response argued that it had immunity from this lawsuit. ${ }^{213}$ The court rejected this argument, concluding that once the FBI had

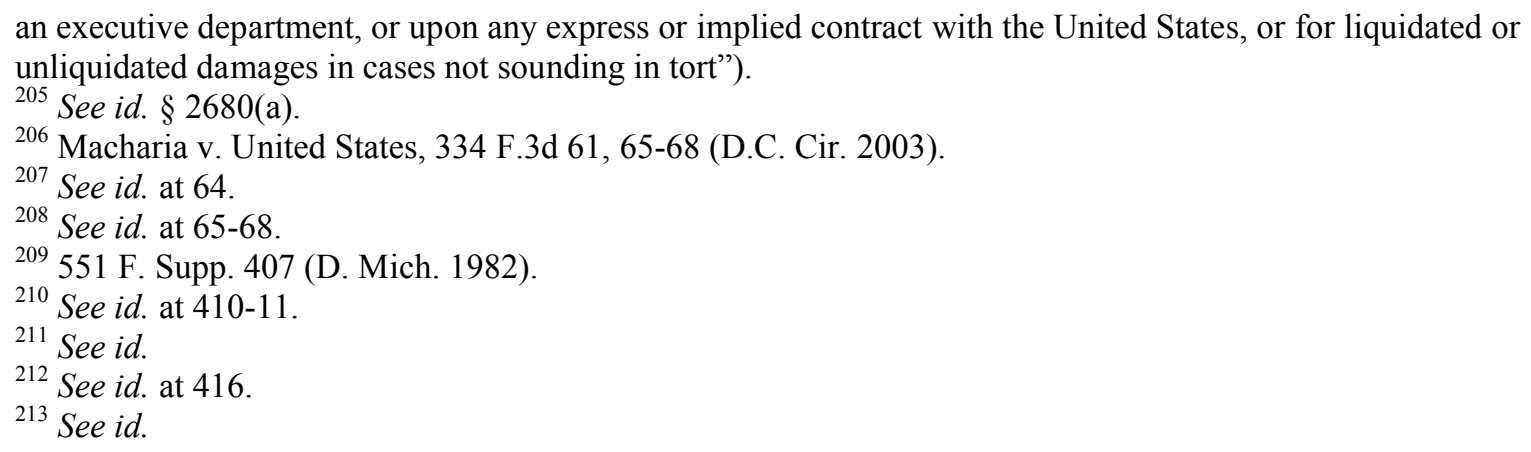


undertaken to stop crime, it had a duty not to perform this undertaking in a negligent manner. ${ }^{214}$ It therefore allowed the plaintiffs to bring lawsuits under the Federal Tort Claims Act. ${ }^{215}$ Although few other cases have reached this conclusion, the decision shows how judges may view the government's duty to provide protection against crimes by criminals as something different from the government's duty to provide protection against armed attacks by the enemy.

\section{H. Compensation for Harm}

The government often uses violent measures to respond to terrorism. For example, as described in the section on targeted killing above, ${ }^{216}$ military forces may fire missiles at a terrorist target with the aim of killing the terrorist suspects and destroying their property. Actions of this kind may cause three kinds of damage and injury. First, they may destroy actual terrorist targets, like installations that al-Qaida is using for training or operations. Second, they might damage things that the government believes are terrorist targets but which later turn out not to be. For example, armed forces may destroy a warehouse on the belief that it contains weapons, only to find out later that it contained civilian clothing. Third, they may cause “collateral damage." Collateral damage is "unavoidable and unplanned damage to civilian personnel and property incurred while attacking a military objective."217 For example, when military forces fire missiles at suspected al-Qaida installations, the missiles may destroy not only their targets but also unintentionally wreck nearby structures, vehicles, or other items.

\footnotetext{
${ }^{214}$ See id. at 419.

215 See id. The court did not decide whether the FBI in fact had acted negligently, leaving that matter for trial. See id.

216 See supra part II.C.

217 The Judge Advocate General's Legal CENTER AND School, Operational LAW HandBoOK 14 (Joseph B. Berger et al. eds. 2004), available at <http://fas.org/irp/doddir/army/law2004.pdf >.
} 
When the government destroys property in anti-terrorism operations, a question sometimes arises about whether the government has a duty to pay for it. The question is not difficult when military forces destroy actual terrorist targets: the government does not have to pay. As the United States Court of Appeals for the Federal Circuit has said: "A contrary rule that, by way of example, would require the government to provide compensation for the destruction of a vehicle (a tank, jet, etc.) used to engage United States armed forces in battle, strikes us as absurd in the extreme." 218

But compensation for destruction of supposed terrorist targets that actually are unconnected with terrorism and compensation for collateral damage are more difficult issues. In the United States, the Fifth Amendment says that the government may not "take" private property for public use without paying just compensation to the owner. ${ }^{219}$ Governmental "taking” of property may consist of occupying, destroying, or sometimes merely preventing the owner from using the property. ${ }^{220}$ The rationale appears to be that taxpayers as a group should have to bear the costs of public projects, not just the people whose property is needed. ${ }^{221}$ The innocent owners of property destroyed in anti-terrorism operations thus have some argument that the public should share the expense of these operations. But whether that argument prevails or not depends in large part on whether the government was pursuing the anti-terrorism action as a military matter or as a law enforcement matter.

\footnotetext{
${ }^{218} I d$.

${ }^{219}$ See U.S. Const. amend. 5.

${ }^{220}$ See John E. NowAK \& RonAld E. Rotunda, Constitutional LAW $\S 11.12$, at 438-439 (5th ed. 1995).

${ }^{221}$ See Daryl J. Levinson, Making Government Pay: Markets, Politics, and the Allocation of Constitutional Cost, 67 U. Chi. L. Rev. 345, 391 (2000).
} 
The case of El-Shifa Pharmaceutical Industries Co. v. United States, ${ }^{222}$ concerned an incident that occurred after the 1998 bombings of two United States embassies in Africa. ${ }^{223}$ In response to the bombings, the President ordered the Navy to fire Tomahawk missiles at a pharmaceutical factory in Sudan. ${ }^{224}$ The missiles hit their target and destroyed the facility. The White House explained at the time that the factory had links to al-Qaida and that the factory possibly was producing a chemical used in the manufacture of nerve gas. ${ }^{225}$

The owner of the destroyed pharmaceutical plant subsequently sued the United States in the United States Court of Federal Claims, seeking compensation for the damage under the takings clause of the Fifth Amendment. ${ }^{226}$ The United States asked the court to reject the claim, citing among other principles the rule regarding the destruction of "enemy property" discussed above. $^{227}$ Although the owner argued in response that the military exception should not apply because the factory actually had no connection to terrorism or nerve gas, ${ }^{228}$ the court denied relief. It held that the issue of whether a target was actually enemy property or not was a political question and that the court had to defer to the President's judgment. ${ }^{229}$

In contrast, at least in some jurisdictions, when law enforcement agencies are pursuing criminal suspects and they destroy property belonging to an innocent person, they must pay for

\footnotetext{
222378 F.3d 1346 (Fed. Cir. 2004), cert. denied 125 S. Ct. 2963 (2005).

${ }^{223}$ See supra part II.A. (discussing this incident in connection with the rules regarding the use of force in other countries).

${ }^{224}$ See id. at 1349.

${ }^{225}$ See id.

${ }^{226}$ See id. at 1355 .

${ }^{227}$ See id.

${ }^{228}$ See id. at 1361.

${ }^{229}$ See id. at 1365 ("We are of the opinion that the federal courts have no role in setting even minimal standards by which the President, or his commanders, are to measure the veracity of intelligence gathered with the aim of determining which assets, located beyond the shores of the United States, belong to the Nation's friends and which belong to its enemies. In our view, the Constitution envisions that the political branches, directly accountable to the People, will adopt and promulgate measures designed to ensure that the President makes the right decision when,
} 
the damage. For example, in Wegner v. Milwaukee Mutual Insurance Co., a suspected drug dealer broke into a nearby home while fleeing from the police. ${ }^{230}$ The police fired tear gas and concussion grenades into the home to force the suspect out, causing extensive damage to the building. ${ }^{231}$ The Minnesota Supreme Court held that “where an innocent third party's property is damaged by the police in the course of apprehending a suspect," the government must pay just compensation to the property owner. ${ }^{232}$

Similarly, in Steele v. City of Houston, ${ }^{233}$ a group of escaped prisoners hid out in a vacant home that they had chosen at random. To force them out, the police set fire to the building. ${ }^{234}$ The Texas Supreme Court required the city to pay the property owner for the damage. ${ }^{235}$ The Court said: "We do not hold that the police officers wrongfully ordered the destruction of the dwelling; we hold that the innocent third parties are entitled by the Constitution to compensation for their property." ${ }^{, 236}$ As the New Jersey Supreme Court explained in a similar case when it required the police to pay for doors broken in the execution of a search warrant: "Since the damage was incurred for the public good, rather than for the benefit of the private individual, the public should bear the cost. The intended beneficiary of the police action was not [the innocent property owner], but society as a whole."237

pursuant to his role as Commander-in-Chief, he orders the military to destroy private property in the course of exercising his power to wage war.").

${ }^{230} 479$ N.W.2d 38, 41-42 (Minn. 1991).

${ }^{231}$ See id. at 39.

${ }^{232}$ See id. at 41-42.

${ }^{233} 603$ S.W.2d 786 (Tex. 1980).

${ }^{234}$ See id. at 789.

${ }^{235}$ See id. at 791-92.

${ }^{236}$ Id. at 793.

${ }^{237}$ Wallace v. City of Atlantic City, 608 A.2d 480, 483 (N.J. Super. 1992). For decisions reaching contrary decisions to those described in this paragraph, see Sullivant v. City of Oklahoma City, 940 P.2d 220, 227 (Okla. 1997) (holding that a city does not have to pay for damage to innocent landlord's property and citing similar cases from California, George, Indiana). 
These cases suggest that, if law enforcement officials had destroyed a facility that they thought belonged to a terrorist suspect but that actually belonged to an innocent party, the government would have to pay for the damage caused. The political question doctrine would not protect the government. So victims' rights differ substantially depending on whether the government is pursuing terrorists as enemy combatants or law enforcement agencies are going after terrorists as criminals.

\section{Other Issues}

The first claim in this article is that the dichotomous characterization of counterterrorism measures as either law enforcement or military action has become a central part of anti-terrorism law. The foregoing discussion has demonstrated the validity of this claim. It has shown how the results of this characterization affect not just one or two areas, like detention and interrogation, but many different areas. And it has shown that law enforcement/military action characterization has been important not just in recent years, but for decades, both in the U.S. and abroad.

Yet it is important not to overstate the claim. Although characterization is important, it is not the only issue in determining the legality of governmental responses to terrorism. On the contrary, even if everyone were to agree on how to characterize counterterrorism actions a number of other questions might arise. Some examples of the issues that would remain include:

- when enemy combatants have the rights under the Geneva Convention III; ${ }^{238}$

- when enemy combatants are entitled to "combatant immunity," which is immunity for punishment for lawful acts of war; ${ }^{239}$

\footnotetext{
${ }^{238}$ See, e.g,., Hamdan v. Rumsfeld, 126 S. Ct. 2749, 2794-96 (2006) (concluding that members of al-Qaida have the limited rights afforded by "common article 3" of Geneva Convention 3).
} 
- $\quad$ how to measure the duration of an armed conflict against terrorism for determining how long enemy combatants may be detained; ${ }^{240}$

- what trial procedures military commissions have to follow when they try enemy combatants; $;{ }^{241}$

- what offenses may military commissions punish enemy combatants for having committed, ${ }^{242}$

- what interrogation methods may the military use in attempting to gain information from enemy combatants; ${ }^{243}$

- the extent to which persons held as enemy combatants have a constitutional right to due process ${ }^{244}$ and

- the extent to which citizens who are enemy combatants have different rights from noncitizens. $^{245}$

${ }^{239}$ See, e.g, United States v. Lindh, 212 F. Supp.2d 541, 554-558 (E.D. Va. 2002) (concluding that American citizen who was a member of the Taliban forces and was designated as an enemy combatant did not have combatant immunity).

${ }^{240}$ See Hamdi v. Rumsfeld, 124 S. Ct. 2633, 2641-2642 (2004) (plurality opinion) (stating that the United States ordinarily may detain captured enemy combatants "for the duration of the relevant conflict" but that if "the practical circumstances of a given conflict are entirely unlike those of the conflicts that informed the development of the law of war" a different rule might apply).

${ }^{241}$ Hamdan v. Rumsfeld,

${ }^{242}$ The Department of Defense has defined a set of offenses that military commissions may try. See U.S. Dep't of Defense, Military Commission Instruction No. 2, Crimes and Elements for Trials by Military Commission (Apr. 30, 2003), available at $<\mathrm{http} / / \mathrm{www}$. dtic.mil/whs/directives/corres/mco/mci2.pdf $>$. For a list of legal questions raised by this list of, see Human Rights Watch, Commenting on Draft Military Commission Instruction on "Crimes and Elements for Trials by Military Commission" (Mar. 14, 2003), available at $<$ http://www.hrw.org/press/2003/03/us031403.htm>.

${ }^{243}$ See U.S. Dep't of Defense, DoD Provides Details on Interrogation Process, News Release No. 596-04 (Jun. 22, 2004) (describing interrogation methods and responding to legal criticism), available at $<$ http://www.defenselink.mil/releases/2004/nr20040622-0930.html $>$.

${ }^{244}$ Compare Khalid v. Bush, 355 F. Supp.2d 311, 323 (D.D.C. 2005) (dismissing challenges to the procedures) with In re Guantanamo Detainee Cases, 355 F. Supp.2d 443, 465-66 (D.D.C. 2005) (concluding that the procedures did not meet the requirements of due process).

${ }^{245}$ See Hamdi v. Rumsfeld, 124 S. Ct. 2633, 2641-2642 (2004) (plurality opinion) (asserting the government may detain U.S. citizens who are enemy combatants in the same manner that it detains other enemy combatants) with id. at 2660-61 (Scalia, J., dissenting) (asserting that the government may detain U.S. citizens as enemy combatants only if it suspends the writ of habeas corpus). 
But it is also important not to underestimate the current importance of characterization. Until an initial determination is made that suspected terrorists are enemy combatants, none of the issues listed above immediately come into dispute.

\section{THE PROBLEMS WITH DETERMINING THE LEGALITY OF COUNTERTERRORISM MEASURES BY ATTEMPTING TO CHARACTERIZE THEM AS LAW ENFORCEMENT OR MILITARY ACTIONS}

The previous part of this article has shown that legal systems around the world, for a long time and in a great many different subject areas, have depended on characterization to determine the legality of governmental responses to terrorism. Sometimes they characterize these responses as law enforcement measures and, at other times, they describe them as military efforts in an armed conflict. The characterization selected currently has important legal consequences. Armed forces involved in a war can take actions, such as targeted killing, that the police cannot. ${ }^{246}$ And the police can carry out actions, such as law enforcement duties, that the armed forces cannot. ${ }^{247}$

This "military or law enforcement" classification system for determining the legality of governmental responses to terrorism has four substantial problems. First, no standard currently exists for deciding when terrorists are combatants as opposed to mere criminals, or when antiterrorism actions are law enforcement measures as opposed to military actions in an armed conflict. Second, no clear standard is likely to emerge in the future because terrorists defy a simple characterization; they resemble criminal suspects in some respects, and enemy combatants in others. Third, even when characterization is possible, using it to determine what

\footnotetext{
${ }^{246}$ See supra part II.C.

247 See supra part II.B.
} 
laws should regulate governmental responses to terrorism often produces results that are objectionable on policy grounds. Fourth, the current system effectively gives governments extremely broad discretion to determine the legality of their own anti-terrorism actions because their control of the characterization process effectively allows them to select the applicable set of legal rules.

\section{A. No Standard for Making the Characterization Exists}

One fundamental problem with attempting to decide what body of law regulates governmental responses to terrorism is that no commonly accepted or consistently applied standard has developed for deciding whether to characterize terrorists as enemy combatants or ordinary criminals. In fact, disagreement currently exists at two levels.

First, there are opposing views about the fundamental question of whether terrorists who are not sponsored by a state can ever fall into the category of enemy combatants. As described above, components of the United Nations appear to reject the position of most of the world's leading democracies on this issue. The International Court of Justice, for example, said in the Israeli Fence case that terrorists cannot engage in "armed attacks" because they are not states. ${ }^{248}$ This position fundamentally conflicts with the unanimous view of all of the members of NATO, which viewed the attacks of September 11, 2001, as an armed attack. ${ }^{249}$

Second, even those who agree that terrorists in proper circumstances can be viewed as enemy combatants have not established exactly what those circumstances are. The United

\footnotetext{
${ }^{248}$ See supra part II.A.

${ }^{249}$ See id.
} 
States, for instance, repeatedly has seen terrorist strikes as acts of war. ${ }^{250}$ And yet the United States has not articulated a clear standard through which it has made that characterization. In domestic legal cases, the United States has consistently decided not to express a standard; instead, it has told the judiciary that it should defer to the determinations of Congress and the President. ${ }^{251}$ The federal courts generally have granted this deference. ${ }^{252}$ In international contexts, where the United States cannot rely on deference, the government has offered some brief substantive explanations for its characterization of terrorists as combatants. But these explanations lack definiteness. For example, as explained above, following the United States' targeted killing of al-Qaida suspects in Yemen, the United Nations Special Rapporteur for ExtraJudicial Killings demanded that the United States explain why the suspects should not have received ordinary criminal justice protections. ${ }^{253}$ In response, the United States offered this explanation: "Al Qaida and related terrorist networks are at war against the United States. They have trained, equipped, and supported armed forces and have planned and executed attacks around the world against the United States on a scale that far exceeds criminal activity."254

In the quoted passage, the United States appears to have taken the position that the magnitude of the terrorist incident or incidents determines whether law enforcement principles or the law of war govern anti-terrorism responses. A focus on the size of the terrorist attacks has some justification. Certainly, it accords with general understandings about one important

\footnotetext{
${ }^{250}$ See id.

${ }^{251}$ See Brief for the Respondents at 20, Hamdi v. Rumsfeld, 2004 WL 724020 (U.S.) (No. 03-6696) (arguing that Congress had authorized the use of military force against terrorists in Afghanistan); id. at 25 ("The Executive's Determination That An Individual Is An Enemy Combatant Is Entitled To The Utmost Deference By A Court"). ${ }^{252}$ See Hamdi v. Rumsfeld, 124 S. Ct. 2633, 2648 (U.S. 2004) (plurality opinion) (deferring to the President on the issue of whether a class of terrorists might be viewed as enemy combatants, but specifying procedures for determining whether an individual belongs to the class).

${ }^{253}$ See supra Part II.C.

${ }^{254}$ U.S. Yemen Response, supra note 102, at 3 (emphasis added).
} 
difference between ordinary crimes and acts of war. And it can explain why the United States felt justified in using military actions in response to al-Qaida's destruction of the United States' embassies in Kenya and Tanzania in 1998, for the bombing of the U.S.S. Cole in 1998, and the attacks of September 11, 2001. ${ }^{255}$ All of these incidents caused many deaths and great destruction of property.

But can a magnitude standard explain the United States' military assault on Libya in response to the 1985 bombing of the Berlin discotheque? That terrorist attack resulted in two deaths. ${ }^{256}$ It thus does not appear to have had a "scale that far exceeds criminal activity." And if magnitude is the test, why did the United States not treat Timothy McVeigh or the 1993 World Trade Center bombers as enemy combatants? McVeigh's terrorist attack on the Murrah Federal Building in Oklahoma City killed 168 people, ${ }^{257}$ while the World Trade Center bombing caused six deaths and hundreds of millions of dollars in property loss. ${ }^{258}$ Yet, the United States subjected the perpetrators of these terrorist incidents to ordinary criminal process. ${ }^{259}$ These questions remain unanswered.

In short, despite the great importance currently placed on characterization for determining governmental powers and individual rights, no international consensus exists on when to characterize terrorist suspects as enemy combatants as opposed to ordinary criminals. And the United States' proffered standard of magnitude is both under-inclusive and over-inclusive, at least in terms of the United States' past practice.

\footnotetext{
${ }^{255}$ Parts II.A \& II.C. supra describe these incidents.

${ }^{256}$ See John Tagliabue, 2 Killed, 155 Hurt in Bomb Explosion at Club in Berlin, N.Y. TIMES, Apr. 6, 1986 , at 1.

${ }^{257}$ See United States v. McVeigh, 153 F.3d 1166, 1176 (10th Cir. 1998).

${ }^{258}$ See United States v. Salameh, 152 F.3d 88, 108 (2d Cir. 1998).

259 See id. (describing criminal charges); McVeigh, 153 F.3d at 1176-77 (same).
} 


\section{B. Counterterrorism Measures Fit Neither Characterization Perfectly}

Not only has no consensus developed on when to judge anti-terrorism responses as law enforcement measures and when to judge them as steps taken in an armed conflict, but it also seems unlikely that any agreement on a test ever will emerge. This prediction rests on the simple observation that most acts of terrorism have a dual nature: they resemble warfare in some respects and crimes in others. And this dual nature prevents easy characterization of governmental response. Most terrorist acts resemble crimes because they are crimes. Murder is murder, assault is assault, and kidnaping is kidnaping, regardless of whether a terrorist or a mobster or street thug commits them. Consequently, at least in the United States, prosecutors can and routinely do prosecute terrorists using ordinary criminal laws. ${ }^{260}$

Terrorists also often resemble criminals in terms of strategy. Terrorists, like most criminals, usually pick easy, high value targets. Unlike military forces, terrorists and criminals generally do not strive to use overwhelming force against the most significant enemy strengths with the goal of obtaining a clear and incapacitating victory. To succeed, terrorists generally do not need to cause crushing devastation any more than bank robbers need to destroy the banking system.

On the other hand, terrorist organizations have many features in common with military forces. First, terrorists commonly use military weapons to commit their acts. For example, members of the terrorist organization Hamas routinely hit Israeli targets using mortars and rockets located in the West Bank or in Gaza. ${ }^{261}$ Second, terrorists also tend to strike military targets that ordinary criminals would have little interest in assaulting. For example, no one but

\footnotetext{
${ }^{260}$ See MAGGS, supra note 1, at 5-10 (addressing the application of ordinary criminal laws to terrorists).
} 
terrorists or an opposing Navy would have an interest in trying to sink the U.S.S. Cole. Third, terrorist organizations may have capabilities that outmatch those of law enforcement agencies. If the combined military forces of the United States and its many allies need years to subdue alQaida agents in Afghanistan, certainly no police force could accomplish the same mission. Fourth, in many instances, as the United States has argued, ${ }^{262}$ acts of terrorism exceed ordinary criminal conduct in magnitude. Strikes like those of September 11, 2001, cause death and destruction far beyond anything a typical criminal would ever attempt. Fifth, terrorist organizations also often resemble military forces more than criminals in terms of their persistence and their depth of capacity. When a member of a terrorist organization is arrested or killed, instead of halting its operations, the organization generally finds a replacement and continues its plans. In contrast, if the police thwart a bank robbery by arresting the would-be perpetrator, often no subsequent robbery is likely to occur. This feature of terrorist organizations makes them much more difficult to eradicate. Sixth, terrorists routinely take credit for their actions. They want the world to know what they have done; that is the whole point of their infliction of pain. In this way, terrorists resemble armed forces more than criminals, who generally hope to avoid identification and blame.

Finally, and perhaps most significantly, most acts of terrorism resemble acts of wars more than criminal acts in terms of their most basic motivations. Governments fight wars in the belief that organized violence will accomplish political ends that diplomacy cannot. Although their methods are unlawful, terrorists generally act for similar reasons. But criminals generally have more selfish goals; they commit offenses to line their pockets with money or harm their

${ }^{261}$ See Greg Myre, Israel Carries Out First Airstrike, in Gaza, in 3 Months of Truce, N.Y. TIMES, May 19, 2005, at A11. 
personal enemies, but not to cause political change. In fact, some definitions of terrorism focus primarily on motivation to distinguish it from ordinary crime. ${ }^{263}$

Terrorists, acts of terrorism, and governmental responses to terrorism for these reasons all have a dual nature. They fall partly within the realm of crime and law enforcement and partly within the realm of armed conflict and military force. They generally defy characterization as one or the other.

\section{Either Characterization Sometimes Produces Unfavorable Results}

Even if a clear test emerged for deciding when terrorist acts move beyond being mere crimes and instead become acts of war, another difficulty would remain: In many situations, the unlimited application of either the laws of war or the laws regarding criminal law enforcement to counterterrorism measures seems problematic from a policy perspective. The laws of war often appear to afford the government more power than it needs to combat terrorism, while the rules regarding law enforcement often provide too little.

To see this point, assume that the United States is correct that the various attacks perpetrated by al-Qaida do constitute acts of war. Using the usual characterization approach, it follows then that members of al-Qaida are enemy combatants. And it further follows that the law of war governs their treatment.

Applying the law of war seems uncontroversial when the United States is attacking armed formations of al-Qaida forces in Afghanistan. For example, most would agree that the

\footnotetext{
262 See supra part III.A.

${ }^{263}$ See United States v. Yousef, 327 F.3d 56, 107 n.42 (2d Cir. 2003).
} 
United States may use deadly force against these enemies without first trying to arrest them. ${ }^{264}$ Indeed, given that al-Qaida forces remain active in Afghanistan despite years of eradication attempts by 20,000 American and allied military personnel, any suggestion that the FBI as opposed to the Armed Forces should have gone to Afghanistan to arrest the perpetrators of the 9/11 attacks seems hopelessly unrealistic.

But even if members of al-Qaida are enemy combatants, it may not follow that the United States should, as a policy matter, have the power to use all of the military force against all alQaida members that the laws of war would allow it to use against more conventional enemy combatants. Consider again the case of Jose Padilla, the American citizen who according to stipulated facts went to Afghanistan, fought with al-Qaida against the United States, fled to Pakistan, and then returned to the United States, where U.S. marshals arrested him at Chicago's O'Hare airport. ${ }^{265}$ A great deal of controversy has surrounded Padilla's prolonged detention. But ignore the detention issue for a moment and think instead about what the United States might have done at the airport when Padilla stepped off the airplane. If Padilla is truly an enemy combatant, then one school of thought might say that the United States could have shot him immediately, without first attempting to arrest him. After all, the law of war permits this kind of force-targeted killing —against enemy combatants.

But I suspect that most people would think that simply shooting Padilla at the airport would be wrong. The United States did not take that action. And when asked during oral argument at the Supreme Court whether it could have done so, counsel for the government

\footnotetext{
${ }^{264}$ The laws of war long have permitted the killing of enemy forces, who have not already surrendered, without any resort to lesser messages. See supra part II.C.

${ }^{265}$ See id. (discussing the Padilla case).
} 
tactfully avoided the question. ${ }^{266}$ Presumably the government also felt uncomfortable about the logical consequences of its contentions that Padilla is an enemy combatant and that the laws of war therefore should govern his treatment.

The "either law enforcement or military action" approach also may fail to accord with widely accepted views when it prevents certain military responses to terrorism. For example, consider again the case of John Muhammad and Lee Malvo, the notorious "D.C. snipers." ${ }^{267}$ As described above, observers disagreed about whether the military was violating the Posse Comitatus Act by assisting law enforcement. ${ }^{268}$ But even assuming that everyone were to agree that the Army was assisting in law enforcement, most people would not consider this assistance inappropriate from a policy perspective. As one New York Times reporter put it, "[f]or thousands of people in the Washington region ducking behind their cars as they pump gas, keeping their children indoors or missing the high school football season, there is no limit to what should be done to thwart the sniper who has shot 11 people this month."269 Thus, the difficulty of classifying the antiterrorism measures is only part of the problem with the current legal rules. Another part of the problem is that the full application of either law enforcement rules or the

\footnotetext{
${ }^{266}$ During the Supreme Court oral argument in Padilla v. Rumsfeld, 524 U.S. 425 (2004), counsel for the United States, Deputy Solicitor General Paul D. Clement, argued that the Padilla could be treated just like any enemy combatant found in Afghanistan. This assertion prompted the following exchange between Justice Anthony M. Kennedy and Mr. Clement: QUESTION: Would you shoot him when he got off the plane? MR. CLEMENT: No, I don't think we could for good and sufficient reasonsQUESTION: I assume that you could shoot someone that you had captured on the field of battle. MR. CLEMENT: Not after we captured them and brought them to safety. And I think in every case, there are rules of engagement, there are rules for the appropriate force that should be used.

Tr. of Oral Arg., Padilla v. Rumsfeld, 2004 W.L. 1066129 (U.S.) (No. 03-1027). Notice that Mr. Clement did say whether the United States could have shot Padilla before he was captured; he avoided the question.

${ }^{267}$ See supra part II.B.

${ }^{268}$ See id.

${ }^{269}$ Adam Clymer, Big Brother Joins the Hunt for the Sniper, N.Y. TIMES, Oct. 20, 2002, at 4-1. At the time of this article, it was assumed there was just one sniper working alone.
} 
laws of war often does not make sense from a policy perspective even if characterization can occur.

\section{The Current System Gives the Government Considerable Discretion to Determine the Legality of its Own Action}

A further problem with reliance on dichotomous characterization is that governments now have a great deal of discretion, after terrorist acts have occurred, to determine what law will apply to the government's anti-terrorism responses. This discretion has predictable consequences. If governments believe that rules governing law enforcement offer them an advantage, they will treat the matter as a criminal incident. But if they think that the law pertaining to military force will yield more favorable results, they will label the terrorists involved as enemy combatants and proceed accordingly.

The possibility that the government may have some choice over which body of law applies to a governmental action by itself is not alarming. On the contrary, this possibility exists in many different contexts. But generally, when the government has choices of this kind, it also faces tradeoffs; the government usually cannot have its cake and eat it too. For example, in the area of military justice, military commanders generally have a choice of referring charges of misconduct to a summary court-martial, a special court-martial, or a general court-martial. ${ }^{270}$ Each of these courts-martial operates under different procedures. At a summary court-martial, for instance, the charges are decided by a single military officer who generally is not a military judge. ${ }^{271}$ At a general court-martial, by contrast, the accused has a right to be tried by a court

\footnotetext{
${ }^{270}$ See 10 U.S.C. $\$ 816$.

${ }^{271}$ Id. $\S 816(3)$.
} 
consisting of a military judge and not less than five service members. ${ }^{272}$ But a summary courtmartial can impose only a limited range of punishments; it cannot order confinement for more than a month. ${ }^{273}$ A general court-martial, in contrast, can impose life imprisonment or even the death penalty. ${ }^{274}$ So a commander has a choice in referring charges to a court-martial but also faces a tradeoff. The summary court-martial has simpler and speedier procedures but is limited in its power, while the general court-martial has greater powers but affords the accused greater procedural protections. The existence of this tradeoff preserves flexibility, without giving commanders unlimited discretion at the expense of the accused.

This kind of tradeoff generally does not exist in the area of counterterrorism. Consider once more the case of Jose Padilla, the American citizen who took up arms against the United States in Afghanistan before being captured in Chicago. ${ }^{275}$ As described above, the government initially held him as a witness in a grand jury investigation. But when that law enforcement characterization was not sufficient to permit his continued detention, and the government apparently lacked probable cause to charge him with a crime, the President designated him as an enemy combatant. The federal courts subsequently have upheld his continued confinement under this designation. ${ }^{276}$ But then inexplicably the government reclassified him as a criminal suspect and brought criminal charges against him. There was never any tradeoff involved; the government did not have to give up anything; it was free to switch between one characterization and the other as it wished.

\footnotetext{
${ }^{272}$ See id. $\S 816(1)(\mathrm{A})$.

${ }^{273}$ See id. $\$ 820$.

${ }^{274}$ See id. $\$ 818$.

${ }^{275}$ See infra part II.D.

${ }^{276}$ Padilla v. Hanft, 423 F.3d at 389-90.
} 
In addition, in most other contexts in which the government has the power to exercise discretion, some legal standard governs the exercise of that discretion. In investigating criminal activity, for example, the government has discretion to decide what searches to conduct. It may choose to search some premises but not others. But in exercising this discretion, the government always faces a restriction. The Fourth Amendment imposes a standard of reasonableness on all searches. ${ }^{277}$ This standard, although open-ended, nevertheless constrains the government's choices. $^{278}$ And courts stand ready to enforce this standard. ${ }^{279}$

But again nothing comparable exists when it comes to the characterization of governmental responses to terrorism as either law enforcement measures or actions taken in an armed conflict. The President simply decides whether to characterize a person as an enemy combatant as opposed to an ordinary criminal suspect. In the United States, the courts defer to this decision. ${ }^{280}$ And in the international sphere, although disagreements have arisen, the United States and other countries usually just ignore opposing views. For example, although the United Nations General Assembly condemned the United States' bombing of Libya, and the U.N. Special Rapporteur for Extra-Judicial Killings condemned its targeted killing of suspected members of al-Qaida, the United States government could and simply did disregard their views. $^{281}$

\footnotetext{
${ }^{277}$ See U.S. Const. amend. 4 (protecting a "right of the people to be secure in their persons, houses, papers, and affects, against unreasonable searches and seizures").

${ }^{278}$ See, e.g., Bond v. United States, 529 U.S. 334, 335 (holding that "a law enforcement officer's physical manipulation of a bus passenger's carry-on luggage violated the Fourth Amendment's proscription against unreasonable searches").

${ }^{279}$ See Weeks v. United States, 232 U.S. 383, 391-92 (1914) (establishing an exclusionary rule for improperly obtained evidence as a means of enforcing the Fourth Amendment); Mapp v. Ohio, 367 U.S. 643, 655 (1961) (applying this rule to the states).

${ }^{280}$ See Padilla v. Hanft, 423 F.3d at 395 (reversing the district court, which attempted to curb the President's discretion by "effectively imposing upon the President the equivalent of a least-restrictive-means test").

${ }^{281}$ See supra part I.A.
} 
In making these criticisms, I do not mean to suggest that the United States or other countries have made incorrect choices when exercising the discretion that they currently have. On the contrary, in the examples discussed, legal and policy arguments may support the characterization of Jose Padilla either as an enemy combatant or as a criminal suspect, the bombing of Libya, and the targeted killing in Yemen. ${ }^{282}$ But even if governments make correct choices, they are still operating in a system that involves no tradeoffs, no standards, and not very much review. A system of this kind over time may give rise to abuse.

\section{THE ADVANTAGES OF SEEING COUNTERTERRORISM MEASURES AS A SEPARATE FORM OF GOVERNMENTAL ACTION}

The forgoing parts of this article have attempted to establish the validity of two claims.

The first claim is that the legality of a wide range of governmental responses to terrorism depends, and for a long time and in many different countries has depended, on a question of characterization. What governments may and may not do turns on whether terrorists are seen as criminals or enemy combatants, whether their deeds are seen as crimes or acts of war, and whether the government responds with law enforcement officers or armed forces. The second claim is that this emphasis on characterization as either law enforcement or military action presents various problems. No standard currently exists or in all likelihood will emerge for making the required characterization. Determining which law will apply by means of this characterization often produces bad results from a policy perspective. And governments

\footnotetext{
${ }^{282}$ See Padilla v. Hanft, 423 F.3d at 395 (explaining why the President could designated Padilla as an enemy combatant and detain him); Ian Johnstone, The Plea of "Necessity" in International Legal Discourse: Humanitarian Intervention and Counter-terrorism, 43 COLUM. J. TRANSNAT'L L. 337, 374 (2005) (discussing the argument that the bombing of Libya could be justified provided that it was a response was aimed at preventing "planned future attacks and if the response had been against the source of the attacks").
} 
generally have broad, standardless, and effectively unreviewable discretion in characterization, making abuse possible.

This part of the article now makes a third claim: In the future, it would be better to view counterterrorism measures as a separate form of governmental action, a form which is not law enforcement and also not military action. The legality of counterterrorism measures then should be judged by new standards, not the rules of criminal procedure and not the laws of war. What are these new standards? They have not been developed yet. Whoever creates them could borrow from both the civilian law enforcement rules and the law of armed conflict or could make altogether new rules. But the content would turn on deliberate policy choices, and not on the awkward initial characterization of whether the terrorists are committing crimes or fighting a war.

\section{A. Benefits of Judging Counterterrorism Measures as Counterterrorism Measures}

Creating specialized standards to assess the legality of governmental responses to terrorism could address problems with the current system in several ways. First, specialized standards would reduce or eliminate the difficulties associated with the indeterminate task of characterizing terrorists as criminals or enemy combatants and characterizing their assaults as crimes or acts of war. Instead, specialized standards could view counterterrorism measures for what they are: actions take against persons who share some of the characteristics of both criminals and enemy combatants. Here are three examples of what I am talking about:

Example \#1. Suppose that the Department of Defense adopts a new regulation saying that the military may assist law enforcement in tracking snipers suspected of having killed more 
than three persons (like the snipers who terrorized the Washington, D.C., area in 2002). ${ }^{283}$ Someone then immediately questions the legality of this regulation. Under existing law, a court would decide the question by determining formalistically whether the military is engaged in a law enforcement action (which might violate the Posse Comitatus Act) or a military action (which would not violate the act). Wouldn't it be better to have a system that focused attention on the question whether the Department of Defense regulation is justified as a policy matter based on its advantages and disadvantages?

Example \#2. Suppose a terrorist group launches a terrorist strike against Americans and their property and then flees to a well-known terrorist training camp in a foreign country. The United States fires a missile at the camp and kills the perpetrators. Currently, the legality of this action would depend on its characterization. Is the United States using military force extraterritorially in response to a mere crime? Is it killing criminal suspects without attempting to arrest them? Or is it fighting a war against enemy combatants? Those are the questions that are now asked. ${ }^{284}$ But wouldn't it be a better system to have a specific standard for judging the legality of this kind of governmental response to terrorism - a standard developed after careful consideration as to whether it would be a good idea for a nation to have the power to launch missile strikes against suspected terrorists located in a foreign country?

Example \#3: To return to the Jose Padilla example, suppose military forces shot him at O'Hare airport as he stepped off the plane. Is this action lawful? If it is a law enforcement action it is not. But if it is a military action, perhaps it is. ${ }^{285}$ But shouldn't the answer turn not on characterization, but on some assessment of what is a good rule and what is not? Maybe there

\footnotetext{
${ }^{283}$ See supra parts II.B. \& III.C. (discussing the D.C. sniper incident).

${ }^{284}$ See supra part I.A.
} 
should be a third standard to regulate force against terrorists, which could say that — regardless of what the police can do to criminals and the military can to do to enemy combatants - the government cannot carry out a targeted killing against an unarmed terror suspect in the United States who does not pose an immediate threat. ${ }^{286}$

Viewing counterterrorism as counterterrorism could narrow the government's discretion to choose the law that applies to its own conduct. Rather than having the government decide on a case-by-case basis and in an unreviewable manner whether a person accused of terrorism is a criminal suspect or an enemy combatant - and in this way determine what legal rules will regulate the government's actions toward him or her - a specialized law might channel the government's actions. For example, a specialized law might allow the President to detain terrorist suspects as enemy combatants, but provide that detainees who could be charged with a crime have certain rights that criminal defendants enjoy. These rights might include, in perhaps a modified form, the right to appear before a magistrate or the right to remain silent. This kind of standard would narrow the differences in treatment of persons detained as enemy combatants and persons detained as criminal suspects.

\section{B. How to Change the Current Approach}

Although this article has advocated the creation of specialized standards for assessing the legality of counterterrorism measures, it cannot hope to specify the precise content of these specialized laws. What the new laws should say is a complicated subject that will require long debate and compromise, in Congress, in the negotiation of international treaties, and elsewhere.

${ }^{285}$ See supra part III.C. 
Further academic work may provide guidance in particular areas. But for now, here are four general thoughts regarding various aspects of the development of these new specialized standards.

First, whoever makes the standards should base their content on policy considerations rather than on existing doctrinal categories. In general, they should seek to determine what rights terrorist suspects ought to have, and what powers military forces and government agencies should have, based on American values and the practical needs of the current situation.

For example, suppose a new treaty is negotiated regarding detention of terrorist suspects captured on the battlefield. The drafters should consider as a policy matter how long the military actually needs to detain them. They then should devise a rule that will meet this need while otherwise preserving the value of liberty. The rule need not specify that the military may hold the suspects for the duration of the conflict simply because the laws of war would permit such detention if terror suspects were ordinary enemy combatants. ${ }^{287}$

By the same token, lawmakers generally should avoid creating antiterrorism rules based solely on legal precedent. Relying exclusively on precedent generally will not do much to address the problems, described above, ${ }^{288}$ that are associated with the current characterization system. For example, a common form of argument, frequently heard in debates about antiterrorism policy, runs as follows: "In World War II, the United States lawfully did X to the Nazis because they were enemy combatants. Terrorists are also enemy combatants. Therefore the law should say that the United States can do X to terrorists." At present, the United States

\footnotetext{
${ }^{286}$ The Public Committee Against Terrorism in Israel essentially argued for this position in its brief before the Israeli Supreme Court. See supra part II.C.

${ }^{287}$ See Hamdi v. Rumsfeld, 542 U.S. at 518 (plurality opinion).

${ }^{288}$ See supra part III.B.
} 
generally can justify its actions as a legal matter based on such reasoning, ${ }^{289}$ but shaping new specialized laws on precedent may simply replicate the difficulties that reliance on characterization currently is causing. It would be better to consider the needs of the current situation and act accordingly.

Second, the Constitution may impose some limits on the creation of specialized standards to regulate governmental responses to terrorism. For example, if the Fourth Amendment requires a search warrant in a particular situation, then Congress cannot pass a new antiterrorism law dispensing with the requirement. But this possibility should not preclude all new law development. Treaties or legislation always could grant additional rights to terrorists who are now classifiable as enemy combatants and who therefore enjoy limited, if any, protection of the Fourth Amendment. ${ }^{290}$ Congress also can alter or change existing statutory rules. For example, at present, the Posse Comitatus Act prohibits the military from helping civilian agencies in searches and seizures for the purpose of law enforcement. ${ }^{291}$ But nothing in the Constitution would prevent Congress from creating exceptions to this statute for terrorism cases.

International treaties also may restrict the United States in reforming its law. For example, the United Nations Charter imposes limitations on the use of force and the International Covenant on Civil and Political Rights specifies requirements for domestic trials. ${ }^{292}$ The United States cannot rewrite international treaties by itself. But it may have the option to withdraw from them, to derogate from their provisions, or to work with other signatories for their amendment or reinterpretation.

\footnotetext{
${ }^{289}$ See 542 U.S. at 518 (relying on World War II-era precedent regarding unlawful combatants).

${ }^{290}$ See supra part II.F.

${ }^{291}$ See supra part II.B.

${ }^{292}$ See supra part II.A.
} 
Third, past experience and other factors suggest that the United States in many instances should expect to lead the way in the creation of the specialized laws on terrorism. The United States developed individual domestic civil and political rights that subsequent international human rights agreements, like the International Covenant on Civil and Political Rights, later copied. $^{293}$ Similarly, the United States' codification of the laws of war in the Lieber Code of 1863 provided the basis for subsequent international agreements on the subject. ${ }^{294}$ If the United States chooses rules wisely, other nations are likely to follow them.

The United States ought to accept most of the burden of drafting and lobbying to bring into force new international rules regarding terrorism. It should take on these tasks because the world's other leading democracies simply have less experience and less at stake in dealing with terrorists outside of their borders. Even in Afghanistan, where allies from twenty nations are fighting the war against al-Qaida, ${ }^{295}$ the ultimate responsibility for handling prisoners falls on the United States. Reported information reveals that besides the United States, only Canada (which has the second largest contingent of forces in Afghanistan ${ }^{296}$ ) has captured appreciable numbers of suspected terrorists in the country, and Canada reportedly turns these suspects over to the United States for detention and interrogation. ${ }^{297}$

\footnotetext{
${ }^{293}$ David P. Stewart, United States Ratification of the Covenant on Civil and Political Rights: the Significance of the Reservations, Understandings, and Declarations, 42 DEPAUL L. REV. 1183, 1188-1189 (1993) ("almost all of the individual rights and freedoms embodied in the Covenant have long been enjoyed by Americans by virtue of the U.S. Constitution and the constitutions and laws of the states").

${ }^{294}$ See Jordan J. Paust, Dr. Francis Lieber and the Lieber Code, 95 AM. Soc'Y InT'L L. PROC. 112, 114 (2001); Grant R. Doty, The United States and the Development of the Laws of Land Warfare, 156 MIL. L. REV. 224, 232 (1998).

${ }^{295}$ See Combined Forces Command-Afghanistan, Fact Sheet, available at http://www.cfca.centcom.mil/Information/Coalition\%20forces\%20in\%20Afghanistan.htm>.

${ }^{296}$ See American Forces Press Service, Canadian Military Assumes Command of Afghanistan PRT, available at http://www.defenselink.mil/news/Aug2005/20050817_2466.html (Oct. 19, 2005) (Canada has more than 1500 troops in Afghanistan).

${ }^{297}$ See Bruce Campion-Smith, Elite Force in Afghan Terror Raids, Toronto STAR, Sept. 21, 2005, at A07.
} 
Finally, no one needs to create a comprehensive new anti-terrorism legal regime all at once. This essay has identified difficulties in many different areas of the antiterrorism law that stem from a reliance on a law enforcement vs. military action characterization to determine the powers of the government. Coming up with standards to judge the legality of counterterrorism responses could occur gradually. For example, new standards first might address the subject matter of interrogation. Then later, they might be crafted for detentions or targeted killing.

\section{For the Skeptical: Consider the Alternatives}

The idea of creating specialized standards to judge the legality of counterterrorism measures initially may not appeal to those actively engaged in the ongoing debates about the lawfulness of military responses to terrorism. Human rights advocates and defense attorneys may fear that new specialized standards will provide fewer protections to suspected terrorists than the criminal justice system currently affords. Similarly, governments using military force to respond to terrorism may fear that, when dealing with terrorists, any departure from the laws governing armed conflict may limit their lawful range of action.

Both sides are probably correct if they hold these views. Any new law specifically addressing terrorism almost certainly will fall somewhere in the middle between the laws of war and the rules governing criminal law enforcement. But opponents of the proposal on both sides should consider the alternative, which is maintaining the status quo.

The current system is dysfunctional for the reasons spelled out in this article. Governments for the most part dismiss critics who say that the law of war does not apply to terrorists. The United States, for example, has told pretty much anyone who has objected, that it 
will forge ahead with targeted killings, detentions, and military commissions because it views suspected terrorists as enemy combatants. But despite the steadfastness of the government's position, its opponents have had an impact. For example, although the President proposed using military commissions to try suspected terrorists in November 2001, the legal proceedings are only just beginning five years later. Why is that? Even though human rights groups have not been able to block the government's plans as a legal matter, they have caused enough commotion to grind the effort almost to a halt. Examples like this show that neither side really is winning in the on-going debate.

New treaties and other laws that establish what governments can and cannot do in combating terrorist threats, without relying on the characterization of terrorists as criminals or enemy combatants, hold potential for ameliorating the situation. These new standards would require tradeoffs, but would provide greater certainty and less controversy. For example, under new laws aimed specifically at terrorism, the government might lose its ability to hold suspected terrorists indefinitely. Or it might lose its ability to conduct targeted killing missions at any time and in any place. But the laws might state clearly when the government may use military force as a counterterrorism measure or when it can engage in searches and seizures to catch terrorists.

\section{Emerging Examples of the Recommended Approach}

Getting away from the current system undoubtedly will prove difficult. But two recent examples illustrate how it might happen. Both of these emerging examples are imperfect, but they do show the general idea. 
Litigants before the Israeli Supreme Court recently disputed the lawfulness of targeted killing. A human rights group called Public Committee Against Torture in Israel sued the government, seeking to enjoin the targeted killing of Palestinian activists. ${ }^{298}$ Its brief described numerous incidents in which Israeli defense forces had located terrorist suspects and then shot them or killed them with explosives. ${ }^{299}$ Like the Special Rapporteur in the Yemen incident, the Public Committee Against Torture in Israel viewed the targeted killings as an impermissible method of law enforcement. Its brief said: "The launching of missiles at a suspected terrorist, at a time when he does not pose immediate danger to another person, is an execution without a trial. The killing of a man by sniper fire, when that man is not engaged in specific activity that endangers the life of another person, is an execution without a trial. Booby trapping the car of a person, as suspect as he may be, is an execution of a person that has not been convicted . ...300

But the Israeli government did not see it that way. It responded by saying that the laws of war allow the Israeli defense forces to attack enemy combatants. Its brief said: "there is no argument [but] that a person who takes a direct part in the hostilities is a legitimate target, whatever his formal characterization (member of a conscription army, uniformed, guerilla fighter, civilian, etc.) may be." ${ }^{301}$

The High Court of Justice did not accept either view. ${ }^{302}$ Instead, it adopted a middle ground. It said that terrorists should be viewed not just as civilians and not just as enemy

\footnotetext{
${ }^{298}$ See H.C. 769/02, Petition for Interim Order, Public Committee Against Torture in Israel v. Israel (2003), available at $<$ http://www.stoptorture.org.il/eng/images/uploaded/publications/17.doc $>$

${ }^{299}$ See id. at 933.

${ }^{300} \mathrm{Id}$. at 914.

${ }^{301}$ H.C. 769/02, Brief for Appellants $\uparrow 18$, Public Committee Against Torture in Israel v. Israel (2003), available at $<$ http://www.stoptorture.org.il/eng/images/uploaded/publications/57.pdf > (quoting State Attorney's Office, Supplementary Statement (Feb. 3, 2003)).

${ }^{302}$ See Public Committee Against Torture in Israel v. Government Of Israel, High Court of Justice of Israel, HCJ 769/02 (2006).
} 
combatants, but instead as a third category that more correctly captures what they are: citizens sometimes taking part in the hostilities. ${ }^{303}$ The Court said that the government may use targeted killing against them when they are engaged in hostilities, but not at other times. ${ }^{304}$ That's a different standard from either what the government advocates based on the laws of war or what the petitioners said about law enforcement rules.

This decision is not a perfect example. It still relies on military/law enforcement characterization to some it extent. It just suggests that the characterization may change over time, depending on what the terrorist is doing. But it is still a good example because it recognizes that the current system is defective and that governmental counterterrorism action does not neatly fit into the category of law enforcement or military action. Rather than sticking with the old rules, the Court tried to think of what made the most sense in judging counterterrorism measures.

Another example is the Military Commissions Act of 2006, which Congress passed following the Hamdan decision. ${ }^{305}$ This act establishes military commissions for trying terror suspects. It is not a perfect of illustration of what this article is talking about because the act is itself a counterterrorism measure, rather than a new standard for judging the legality of counterterrorism measures. But the act does view counterterrorism as something distinct from either law enforcement or military action. The terrorists tried by military commission have rights that criminal suspects have, such as a right to appeal to an article III court. ${ }^{306}$ But the act also treats suspects somewhat like enemy combatants in the sense that it does not give them the benefits of

\footnotetext{
${ }^{303}$ Id. $\mathbf{\top} 37$.

${ }^{304}$ Id. $₫ 38$.

${ }^{305}$ Military Commissions Act of 2006, Pub. L. No. 109-366, 120 Stat 2600 (Oct. 17, 2006).

${ }^{306}$ See id. § 3(a)(1), 120 Stat. 2622 (codified at 10 U.S.C. $§ 950$ ).
} 
all the rules applicable to ordinary criminal trials. ${ }^{307}$ And Congress did not want the act's legality judged by ordinary standards, specifically taking the question of its lawfulness away from the Geneva Conventions. ${ }^{308}$ Congress wanted Courts to judge the act as a unique counterterrorism measure, not strictly as a law enforcement action and not strictly as a military action. More developments along this line should occur in the future.

\section{CONCLUSION}

At present, a specialized law addresses law enforcement agencies' treatment of criminal suspects. And a specialized law governs the military's treatment of enemy combatants. But with rare exceptions, there are no specialized standards for assessing governmental responses to terrorism. This lack of specialized standards necessitates judging the legality of governmental counterterrorism measures by trying to characterize them either as law enforcement or military action. This necessary characterization makes a great deal of difference because the laws applicable to criminal suspects differ a great deal from the laws applicable to enemy combatants. To repeat the clearest example, the former does not allow targeted killing, while the latter appears to do so.

The question thus arises whether this approach produces satisfactory results. This article has argued that it does not. No standard currently exists for correctly characterizing governmental responses to terrorism. Characterization often produces bad results from a policy

\footnotetext{
${ }^{307}$ See id., 120 Stat. 2608 (codified at 10 U.S.C. § 949a(b)(2)(A)) (generally allowing admission of all probative evidence against the accused, without very many specific evidentiary rules).

${ }^{308}$ See id., 120 Stat. 2607 (codified as amended at 10 U.S.C. $\S 948 \mathrm{~b}(\mathrm{~g})$ ) (providing that no alien unlawful combatant could invoke the Geneva Conventions as a source of rights).
} 
perspective. And governments generally have broad, standardless, and effectively unreviewable discretion in making characterizations.

A solution to this problem may lie in creating new specialized standards to govern responses to terrorism. These laws would resemble the law of armed conflict in some respects, but would borrow from ordinary criminal law procedures in other respects. Creating new standards would remove many doubts about the legality of responses to terrorism and would allow policy considerations, rather than the vagaries of characterization, to determine what rules should apply.

Creating specialized laws will take time and it will be difficult. Some will object to limiting the rights currently enjoyed by criminal suspects, while others will lament the loss of authority that they believe the armed forces now enjoy. But as explained previously, both sides might benefit from compromise. And fortunately, the new laws do not have to emerge all at once. Instead, new standards might emerge one at a time to regulate particularly important actions like detention or targeted killing. Israel and the United States have already successfully begun to use this approach. 